\title{
Total Synthesis, Structure Revision, and Absolute Configuration of (-)-Brevenal
}

\author{
Haruhiko Fuwa ${ }^{\dagger}$, Makoto Ebine ${ }^{\dagger}$, Andrea J. Bourdelais ${ }^{\ddagger}$, Daniel G. Baden $\ddagger$, and Makoto \\ Sasaki ${ }^{\star}$ \\ $\dagger$ Laboratory of Biostructural Chemistry, Graduate School of Life Sciences, Tohoku University, Aoba-ku, \\ Sendai 981-8555, Japan \\ $\$$ Wilmington Center for Marine Science, University of North Carolina, 5600 Marvin K. Moss Lane, \\ Wilmington, North Carolina 28409
}

\section{Abstract}

Total synthesis of structure $\mathbf{1}$ originally proposed for brevenal, a nontoxic polycyclic ether natural product isolated from the Florida red tide dinoflagellate, Karenia brevis, was accomplished. The key features of the synthesis involved (i) convergent assembly of the pentacyclic polyether skeleton based on our developed Suzuki-Miyaura coupling chemistry and (ii) stereoselective construction of the multi-substituted $(E, E)$-dienal side chain by using copper(I) thiophen-2-carboxylate (CuTC)promoted modified Stille coupling. The disparity of NMR spectra between the synthetic material and the natural product required a revision of the proposed structure. Detailed spectroscopic comparison of synthetic 1 with natural brevenal, coupled with the postulated biosynthetic pathway for marine polyether natural products, suggested that the natural product was most likely represented by $\mathbf{2}$, the C26 epimer of the proposed structure $\mathbf{1}$. The revised structure was finally validated by completing the first total synthesis of (-)-2, which also unambiguously established the absolute configuration of the natural product.

\section{Introduction}

Marine polycyclic ether natural products continue to fascinate chemists and biologists because of their unique and highly complex molecular architecture coupled with diverse and extremely potent biological activities. ${ }^{1,2}$ Among these, brevetoxin-B, produced by the Florida red tide dinoflagellate, Karenia brevis (formerly known as Gymnodinium breve and Ptychodiscus brevis), is the first member of this class of natural products to be structurally elucidated by spectroscopic and X-ray crystallographic analysis by Nakanishi and co-workers in 1981 (Figure 1). ${ }^{3}$ Ever since, a number of congeners, including brevetoxin-A, ${ }^{4}$ have been isolated and structurally characterized. These toxic metabolites are known to exhibit their potent neurotoxicity by binding with a receptor site 5 on voltage-sensitive sodium channels (VSSC) in excitable membranes, thereby causing the channels to open at normal resting potentials with an increase in mean channel open time and inhibiting channel inactivation. ${ }^{5}$ Blooms of $K$. brevis have been associated with massive fish kills and marine mammal poisoning, and they are thought to be responsible for adverse human health effects, such as respiratory irritation and airway constriction observed in beach-goers during a red tide. In addition, the consumption

E-mail: masasaki@bios.tohoku.ac.jp.

Supporting Information Available: Full experimental details and spectroscopic data for all new compounds, comparison of ${ }^{1} \mathrm{H}$ and ${ }^{13} \mathrm{C}$ NMR spectra for natural brevenal and synthetic 2 , and copies of ${ }^{1} \mathrm{H}$ and ${ }^{13} \mathrm{C}$ NMR spectra for all new compounds (pdf). This material is available free of charge via the Internet at http://pubs.acs.org. 
of shellfish contaminated with brevetoxins results in neurotoxic shellfish poisoning (NSP) in humans, which is characterized by sensory abnormalities, cranial nerve dysfunction, gastrointestinal symptoms, and sometimes respiratory failure. ${ }^{6}$ Hemibrevetoxin-B, another polycyclic ether compound, was isolated by Prasad and Shimizu from the same organism, and the molecular size is about one-half of that of brevetoxins. ${ }^{7}$ Hemibrevetoxin-B was reported to cause the same characteristic rounding of cultured mouse neuroblastoma cells as brevetoxins and show cytotoxicity at a concentration of $5 \mu \mathrm{M}$.

Brevenal, isolated recently by Baden, Bourdelais, and co-workers from the laboratory cultures of $K$. brevis along with brevetoxins, represents the newest member of polycyclic ethers. ${ }^{8}$ The gross structure of brevenal, including the relative stereochemistry, was disclosed in 2004 as structure $\mathbf{1}$ on the basis of extensive 2D NMR studies; however, the absolute stereochemistry remained to be established. Although the size of the molecule is relatively compact compared with brevetoxins, the pentacyclic polyether core arranged with four methyl and two hydroxy groups and, especially, the characteristic heavily substituted left-hand $(E, E)$-dienal side chain make it a synthetically challenging target molecule. In addition, the biological profile of brevenal is particularly unique and intriguing in that it competitively displaces tritiated dihydrobrevetoxin- $\mathrm{B}\left(\left[{ }^{3} \mathrm{H}\right]-\mathrm{PbTx}-3\right)$ from VSSC in rat brain synaptosomes in a dose-dependent manner and antagonizes the toxic effects of brevetoxins in vivo. 8,9 More importantly, picomolar concentrations of brevenal increased tracheal mucus velocity to the same degree as that observed with millimolar concentrations of a sodium channel blocker, amiloride, which is used in the treatment of cystic fibrosis. ${ }^{10}$ Thus, brevenal represents a potential lead for the development of novel therapeutic agents for the treatment of mucociliary dysfunction associated with cystic fibrosis and other lung disorders.

The remarkable structural and biological aspects of this natural product led us to embark on its total synthesis. We have recently reported the first total synthesis of structure 1 originally proposed for brevenal by means of our developed Suzuki-Miyaura coupling-based convergent strategy. ${ }^{11}$ However, the ${ }^{1} \mathrm{H}$ and ${ }^{13} \mathrm{C}$ NMR spectra for the synthetic material were not identical to those reported for the natural product, suggesting that it is necessary to revise the initial structural assignment. Herein, we describe the details of our total synthesis of the proposed brevenal structure $\mathbf{1}$ and non-identity to the natural product. On the basis of the NMR distinctions, a revised structure $\mathbf{2}$, the C26-epimer of $\mathbf{1}$, was proposed and finally confirmed by the total synthesis of (-)-2, which has also led to unambiguous determination of the absolute configuration of the natural product.

\section{Results and Discussion}

\section{Synthesis Plan}

Our total synthesis of structure $\mathbf{1}$ originally proposed for brevenal was based on a retrosynthetic analysis as depicted in Scheme 1. The characteristic unsaturated side chains at both ends of the molecule were to be constructed at a late stage of the total synthesis. The right-hand $(Z)$-diene is the same as that found in the hemibrevetoxin-B structure, and thus this could be prepared by the precedented procedure, namely, selenyl-Wittig reaction using the ylide generated from phosphonium salt $\mathbf{4}$ followed by syn elimination of the selenoxide. ${ }^{12}$ On the other hand, the left-hand side chain that contains a multi-substituted $(E, E)$-dienal moiety was planned to be constructed in a stereoselective manner by the Stille coupling of $(E)$-vinyl iodide $\mathbf{3}$ and $(E)$ vinyl stannane $5 .{ }^{13}$ In turn, the pentacyclic polyether core in $\mathbf{3}$ was envisaged to be available from the AB ring enol phosphate 6 and the DE ring exocyclic enol ether 7 by means of our Suzuki-Miyaura coupling-based chemistry. ${ }^{14-16}$ 


\section{Synthesis of the AB Ring Fragment 6}

The synthesis of the AB ring fragment $\mathbf{6}$ started with Evans aldol reaction of aldehyde $\mathbf{8}$ and oxazolidinone 9, which provided the desired syn-aldol adduct (Scheme 2). ${ }^{17}$ The chiral auxiliary was reductively removed with $\mathrm{NaBH}_{4}{ }^{18}$ to provide 1,3 -diol $\mathbf{1 0}$ as a single stereoisomer in $90 \%$ overall yield. The resultant diol 10 was protected as the $p$ methoxybenzylidene acetal, which was then reduced with DIBALH in a regioselective manner to afford primary alcohol $\mathbf{1 1}$ in $94 \%$ yield for the two steps. ${ }^{19}$ Mesylation of $\mathbf{1 1}$ followed by displacement with sodium cyanide gave nitrile 12 in $96 \%$ yield (two steps). DIBALH reduction of the nitrile and subsequent Wittig reaction of the resulting aldehyde provided $\alpha, \beta$-unsaturated ester 13 in $87 \%$ yield for the two steps. After reduction with DIBALH, Sharpless asymmetric epoxidation of the resultant allylic alcohol 14 under the stoichiometric conditions gave epoxy alcohol 15 in $88 \%$ yield. In contrast, under the catalytic conditions, the yield of 15 was moderate (ca. 50\%) and several unidentified byproducts were formed. Oxidation of 15 followed by Wittig olefination provided vinyl epoxide $\mathbf{1 6}$ in $90 \%$ yield for the two steps. Upon exposure of $\mathbf{1 6}$ to DDQ $\left(\mathrm{CH}_{2} \mathrm{Cl}_{2} / \mathrm{H}_{2} \mathrm{O}\right.$ (20:1), room temperature), deprotection of the PMB group with concomitant 6-endo cyclization took place ${ }^{20}$ to furnish the A ring pyran 17, which was then protected as the TES ether $\mathbf{1 8}$ (89\% yield for the two steps). The relative stereochemistry of $\mathbf{1 7}$ was established by NOE experiments as shown. Hydroboration of $\mathbf{1 8}$ with disiamylborane gave an alcohol (92\% yield), which was then subjected to oxidation and Wittig reaction to afford $\alpha, \beta$-unsaturated ester 19 in $86 \%$ yield for the two steps. Removal of the TES group under mild acidic conditions provided alcohol $\mathbf{2 0}$. Hydrogenation of $\mathbf{2 0}$ with concomitant hydrogenolysis of the benzyl ester, followed by Yamaguchi lactonization, ${ }^{21}$ generated sevenmembered lactone 21 ( $88 \%$ overall yield), which was then transformed to the requisite $\mathrm{AB}$ ring enol phosphate 6 by the usual method. ${ }^{22}$

\section{Synthesis of the DE Ring Fragment 7}

For the synthesis of the DE ring fragment 7, the known seven-membered ether $\mathbf{2 2},{ }^{23}$ corresponding to the D ring, was selected as a starting material (Scheme 3). Benzylation of 22 followed by ozonolysis and reductive workup with $\mathrm{NaBH}_{4}$ gave alcohol $\mathbf{2 3}$ in $96 \%$ yield for the two steps. The primary alcohol of $\mathbf{2 3}$ was protected as the benzyl ether and the benzylidene acetal was removed under acidic conditions to afford diol 24 in a quantitative yield for the two steps. Selective triflation of the primary alcohol followed by TBS protection of the residual secondary alcohol was carried out in one-pot following the method of Mori. ${ }^{24}$ The resulting primary triflate was immediately subjected to nucleophilic displacement with allylmagnesium bromide in the presence of $\mathrm{CuBr}^{25}$ to afford elongated olefin 25 in $85 \%$ overall yield. The terminal olefin of $\mathbf{2 5}$ was oxidatively cleaved $\left(\mathrm{OsO}_{4}, 4\right.$-methylmorpholine $N$-oxide (NMO); then $\mathrm{NaIO}_{4}$ ) to give the corresponding aldehyde, which was treated with 1,3propanedithiol in the presence of boron trifluoride etherate to provide alcohol $\mathbf{2 6}$ after deprotection of the silyl group (88\% yield for the four steps). Hetero-Michael reaction of $\mathbf{2 6}$ with methyl propiolate and 4-methylmorpholine (NMM) followed by hydrolysis of the dithioacetal (MeI, $\mathrm{NaHCO}_{3}$, aq $\mathrm{MeCN}$ ) afforded $\beta$-alkoxyacrylate $\mathbf{2 7}$ in $99 \%$ yield for the two steps. Exposure of 27 to $\mathrm{SmI}_{2}$ in the presence of methanol (THF, room temperature) effected reductive cyclization to form the seven-membered ether, ${ }^{26}$ and after acidic treatment, tricyclic lactone $\mathbf{2 8}$ was obtained in $84 \%$ yield for the two steps as a single stereoisomer. DIBALH reduction of the $\gamma$-lactone and Wittig reaction of the resulting hemiacetal, followed by oxidation of the derived secondary alcohol with tetra- $n$-propylammonium perruthenate (TPAP)/NMO, 27 led to ketone $\mathbf{2 9}$ in $91 \%$ yield for the three steps. At this stage, the stereochemistry at the $\mathrm{C} 27$ position $^{28}$ was confirmed by NOE experiment as shown.

We next investigated stereoselective methylation of ketone 29 using several nucleophiles under various conditions, and the results are summarized in Table 1. Treatment of $\mathbf{2 9}$ with excess trimethylaluminum in $\mathrm{CH}_{2} \mathrm{Cl}_{2}$ produced an approximately 1.3:1 mixture of tertiary alcohols 
30a and 30b along with recovered starting material 29 (entry 1). Exposure of 29 to excess methylmagnesium bromide in THF at $-78^{\circ} \mathrm{C}$ gave a mixture of 30a and 30b with slightly improved diastereoselectivity (ca. 2.5:1 dr), but a significant amount of ketone $\mathbf{2 9}$ was recovered (entry 2). Increasing the reaction temperature dramatically improved the conversion yield without affecting the diastereoselectivity. Thus, treatment of $\mathbf{2 9}$ with 1.5 equiv of methylmagnesium bromide in THF at $-78{ }^{\circ} \mathrm{C}$ to room temperature provided 30a,b in $99 \%$ combined yield (ca. 2.3:1 dr, entry 3). The use of toluene as the solvent led to less favorable ratio (ca. 1:1.3 dr) of products (entry 4). Finally, it was found that addition of methyllithium (1.2 equiv) to 29 in $\mathrm{THF}$ at $-78^{\circ} \mathrm{C}$ followed by gradual warming to room temperature furnished a 10:1 mixture of 30a and 30b in $97 \%$ yield (entry 5). The undesired minor isomer $\mathbf{3 0 b}$ could be easily separated by flash chromatography. Stereochemistry at the C26 tertiary stereocenter of 30a was unequivocally established by NOE between $26-\mathrm{Me}$ and $27-\mathrm{H}$. The corresponding NOE was not observed for the isomer $\mathbf{3 0 b}$.

Conversion of tertiary alcohol 30a to the DE ring fragment $\mathbf{7}$ was carried out as illustrated in Scheme 4. Thus, 30a was protected with TBSOTf and triethylamine to give the TBS ether 31. Hydroboration of the terminal olefin and removal of the benzyl groups under hydrogenolysis, followed by $p$-methoxy-benzylidene acetal formation, led to primary alcohol 32 in $80 \%$ yield for the three steps. Benzylation followed by reductive cleavage of the acetal with DIBALH provided alcohol $\mathbf{3 3}$ (85\% yield, two steps). Finally, iodination and subsequent base treatment furnished the DE ring exo-olefin fragment 7 in $99 \%$ yield for the two steps.

\section{Construction of the Pentacyclic Polyether Core}

With the requisite fragments in hand, we set out to assemble the pentacyclic polyether core as summarized in Schemes 5 and 6. Hydroboration of the DE ring exocyclic enol ether 7 with 9$\mathrm{BBN}$ produced the corresponding alkylborane, which was in situ reacted with the $\mathrm{AB}$ ring enol phosphate 6 in the presence of aqueous $\mathrm{Cs}_{2} \mathrm{CO}_{3}$ and $\mathrm{Pd}\left(\mathrm{PPh}_{3}\right)_{4}$ in $\mathrm{DMF}$ at $50{ }^{\circ} \mathrm{C}$ to furnish the desired coupling product $\mathbf{3 4}$ as a single stereoisomer (Scheme 5). The endocyclic enol ether within 34 was then hydroborated with $\mathrm{BH}_{3} \cdot \mathrm{SMe}_{2}$ to give alcohol $\mathbf{3 5}$ (84\% overall yield from 7), which was oxidized with TPAP/NMO to afford ketone $\mathbf{3 6}$ in $98 \%$ yield. At this stage, the newly generated stereocenters at $\mathrm{C} 16$ and $\mathrm{C} 18$ were unambiguously confirmed by NOE experiments as shown. Subsequent stereoselective introduction of the $\mathrm{C} 14$ hydroxy group was successfully achieved by the previously described method. ${ }^{16 \mathrm{c}, \mathrm{d}, 29}$ Thus, treatment of ketone 36 with LiHMDS in the presence of TMSCl and triethylamine gave the corresponding silyl enol ether, which was then treated with $\mathrm{OsO}_{4} / \mathrm{NMO}$ to provide $\alpha$-hydroxy ketone $\mathbf{3 7}$ as the sole product ( $87 \%$ for the two steps).

Subsequent reduction of hydroxy ketone 37 with DIBALH in THF at $-78{ }^{\circ} \mathrm{C}$ provided an approximately 10:1 mixture of cis-diol $\mathbf{3 8}$ and its trans-isomer in $83 \%$ combined yield, along with a $12 \%$ yield of recovered $\mathbf{3 7}$ (Scheme 6). The desired isomer $\mathbf{3 8}$ could be easily separated by flash chromatography. The newly generated stereocenters at the $\mathrm{C} 14$ and $\mathrm{C} 15$ positions were established by derivatization to the cyclopentylidene acetal $\mathbf{3 9}$ and NOE experiments (Figure 2). It is noteworthy that DIBALH reduction of the TES-protected derivative of $\mathbf{3 7}$ led exclusively to the corresponding $\alpha$-alcohol, suggesting the importance of the free hydroxy group. The outcome of this stereoselective reduction of $\mathbf{3 7}$ can be explained as follows. Initially, the C14 hydroxy group reacts with DIBALH to form the corresponding aluminum alkoxide, which coordinates to the adjacent $\mathrm{C} 15$ carbonyl group to form a five-membered chelate structure, thereby blocking the $\beta$-side of the molecule and forcing the second equivalent of the reductant to approach from the less hindered $\alpha$-side.

After protection of $\mathbf{3 8}$ as the bis-TES ether, oxidative removal of the PMB group with DDQ, followed by oxidation of the resulting secondary alcohol with TPAP/NMO, led to ketone $\mathbf{4 0}$ in $88 \%$ yield for the three steps. To complete the $\mathrm{C}$ ring with an angular methyl group at C19, 
ketone $\mathbf{4 0}$ was treated with ethanethiol in the presence of zinc triflate in THF at room temperature to effect deprotection of the TES groups with concomitant formation of a mixed thioacetal to generate $\mathbf{4 1}$ in $79 \%$ yield. ${ }^{30}$ After protection of the secondary hydroxy group as the TBS ether (97\%), introduction of the C19 axial methyl group was next investigated. Although we initially attempted oxidation of the sulfur within $\mathbf{4 2}$ with $m$ CPBA to the corresponding sulfone under various conditions, it became evident that the mixed sulfonyl acetal derived from $\mathbf{4 2}$ was so prone to undergo hydrolysis that we could only obtain the corresponding hemiacetal derivative. Therefore, we decided to avoid isolation of the unstable intermediate and carry out the oxidation-methylation in a one-pot manner. ${ }^{30 \mathrm{a}}$ Thus, after oxidation of 42 with $m \mathrm{CPBA}$ at $-78{ }^{\circ} \mathrm{C}$, excess amount of trimethylaluminum $(3 \times 4$ equiv + 2 equiv) was added and the resulting mixture was allowed to warm to $0{ }^{\circ} \mathrm{C}$. Gratifyingly, this one-pot procedure ensured the desired pentacyclic polyether core $\mathbf{4 3}$ in $92 \%$ yield as a single isomer. The addition of trimethylaluminum in several portions was crucial for the success of the present process. The newly generated stereocenters were unambiguously established on the basis of NOE studies and ${ }^{3} J_{\mathrm{H}, \mathrm{H}}$ data (Figure 3).

\section{Model Experiments for the Synthesis of the Multi-Substituted $(E, E)$-Diene Side Chain}

Having constructed the pentacyclic polyether skeleton, we next turned our attention to construction of the left-hand side chain. The multi-substituted $(E, E)$-dienal side chain is one of the characteristic structural features of brevenal. Although a survey of the literature suggested the difficulty of constructing such a heavily substituted diene system by means of palladium(0)-catalyzed cross-coupling reactions, ${ }^{13}$ we planned to utilize Stille coupling for connecting the $\mathrm{C} 3-\mathrm{C} 4$ bond. We first set out on model experiments in order to explore optimal conditions. (E)-Vinyl stannane 5 and $(E)$-vinyl iodide $\mathbf{4 4}(E: Z=$ ca. 4:1) were chosen as model substrates (Table 2). Stille coupling of $\mathbf{5 a}$ and $\mathbf{4 4}$ under the conventional conditions led to only a trace amount of the desired diene 45a, and significant amounts of the starting materials were recovered (entry 1). We assumed that this disappointing result was attributable to the low reactivity of $\mathbf{5 a}$ and $\mathbf{4 4}$ arising from steric hindrance. We reasoned that use of a soft ligand such as (2-furyl $)_{3} \mathrm{P}$ or $\mathrm{Ph}_{3} \mathrm{As}$, which accelerates the transmetallation step of the catalytic cycle of Stille coupling, ${ }^{31}$ and copper(I) salt as a co-catalyst, which promotes transmetallation of vinyl stannane 5 to a more reactive copper species, ${ }^{32}$ would be favorable in the present case. In the event, under the influence of the $\mathrm{Pd}_{2}(\mathrm{dba})_{3} /(2 \text {-furyl })_{3} \mathrm{P} / \mathrm{CuI}$ or $\mathrm{Pd}_{2}(\mathrm{dba})_{3} / \mathrm{Ph}_{3} \mathrm{As} / \mathrm{CuI}$ catalyst system, Stille coupling of a sterically less encumbered vinyl stannane $\mathbf{5 b}$ and $\mathbf{4 4}$ proved to be very effective, giving diene $\mathbf{4 5 b}$ in acceptable yields (entries 2 and 3 ). However, increasing the reaction temperature to $60^{\circ} \mathrm{C}$ caused significant isomerization of the diene configuration (entries 4 and 5). The structure of the isomerized byproduct, (E,Z)-diene 46, was confirmed by NOE experiments. Gratifyingly, it was found that the use of copper(I) thiophene-2-carboxylate $(\mathrm{CuTC})^{33}$ instead of CuI realized further improvement of the yield of $\mathbf{4 5 b}$ (84\% yield, entry 6). When the TBDPS-protected $\mathbf{5 a}$ was again used as a coupling partner, homocoupling product 47 was formed as a byproduct and hence the yield of the desired 45a was sligtly lowered (entries 7 and 8$)$.

\section{Total Synthesis of the Proposed Structure of Brevenal}

Having secured the reliable reaction conditions for constructing the left-hand side chain, the final stage of the total synthesis of $\mathbf{1}$ was executed as shown in Scheme 7. Reductive removal of the benzyl group from $\mathbf{4 3}$ with $\mathrm{LiDBB}^{34}$ was followed by reprotection as the TBS group to give silyl ether 48 . Selective removal of the primary TBDPS group from $\mathbf{4 8}$ in the presence of the three TBS groups was successfully carried out according to the procedure of Nakata and co-workers, ${ }^{35}$ leading to primary alcohol 49 in $73 \%$ yield after three recycles. ${ }^{36}$ Oxidation of 49 with Dess-Martin periodinane ${ }^{37}$ followed by treatment of the resulting aldehyde with the Ohira-Bestmann reagent $\left(\mathrm{K}_{2} \mathrm{CO}_{3}, \mathrm{MeOH}\right)^{38}$ produced an alkyne, which was then methylated with $n$-butyllithium/methyl iodide to provide alkyne $\mathbf{5 0}$ in excellent overall yield. At this stage, 
the robust TBS protecting groups were replaced with the easily removable TES ethers. Thus, alkyne $\mathbf{5 0}$ was treated with HF•pyridine, and the resulting triol was reprotected with TESOTf and triethylamine to give tris-TES ether 51. Regioselective silylcupration of 51 with $\left(\mathrm{Me}_{2} \mathrm{PhSi}\right)_{2} \mathrm{Cu}(\mathrm{CN}) \mathrm{Li}_{2}{ }^{39}$ delivered the desired vinylsilane $\mathbf{5 2}$ in an approximately 9:1 regioselectivity. The regiochemistry of $\mathbf{5 2}$ was confirmed by the characteristic pattern of the olefinic proton (dd, $J=7.0,7.0 \mathrm{~Hz}$ ). Conversion of $\mathbf{5 2}$ to vinyl iodide $\mathbf{3}$, required for the projected Stille coupling, was performed on exposure to $\mathrm{N}$-iodosuccinimide (NIS) in MeCN/ THF (4:1) at room temperature. ${ }^{40}$ Under these reaction conditions, isomerization of the olefin stereochemistry partially occurred and ca. 6:1 mixture of $(E)$-vinyl iodide $\mathbf{3}$ and its $(Z)$-isomer, along with small amounts of regioisomers, were produced in $99 \%$ combined yield from $\mathbf{5 1}$. The $(E)$-geometry of $\mathbf{3}$ was tentatively assigned because it is well-known that the iododesilylation generally proceeds with retention of configuration, ${ }^{40}$ and this was later confirmed by characterization of the cross-coupled product $\mathbf{5 3}$ (vide infra). Without separation of these isomers, the crucial Stille coupling was carried out under the established conditions. Thus, cross-coupling of $\mathbf{3}$ with vinyl stannane $\mathbf{5 b}$ in the presence of the $\mathrm{Pd}_{2}(\mathrm{dba})_{3} / \mathrm{Ph}_{3} \mathrm{As} / \mathrm{CuTC}$ catalyst system in THF/DMSO (1:1) at room temperature proceeded smoothly to furnish $(E, E)$-diene $\mathbf{5 3}$ in $63 \%$ yield as a single stereoisomer, after purification by flash chromatography. ${ }^{41}$ The stereochemistry of the diene system was unequivocally established by NOE experiments as shown.

After protection of the allylic alcohol of $\mathbf{5 3}$ as the TBDPS ether, the primary TES ether was selectively removed with PPTS to give alcohol $\mathbf{5 4}$ in $74 \%$ yield for the two steps. Introduction of the right-hand $(Z)$-diene side chain was performed without incident according to the procedure of Nicolaou et al. ${ }^{12}$ Thus, oxidation of $\mathbf{5 4}$ with $\mathrm{SO}_{3} \cdot$ pyridine/DMSO followed by Wittig olefination using the ylide, derived from phosphonium salt $\mathbf{4}$, and subsequent hydrogen peroxide treatment led to conjugated $(Z)$-diene $\mathbf{5 5}$ in $\mathbf{7 5 \%}$ overall yield from $\mathbf{5 4}$. Global deprotection of the silyl protecting groups from $\mathbf{5 5}$ by the action of TAS- $\mathrm{F}^{42}$ provided triol 56 in $79 \%$ yield. Finally, chemoselective oxidation of the $\mathrm{C} 1$ alcohol by $\mathrm{MnO}_{2}$ completed the synthesis of the proposed structure $\mathbf{1}$ for brevenal in a quantitative yield.

\section{Revised Structure of Brevenal}

Unfortunately, however, the ${ }^{1} \mathrm{H}$ and ${ }^{13} \mathrm{C}$ NMR spectra of synthetic $\mathbf{1}$ were not identical with those of the authentic sample, suggesting that revision of the originally proposed structure of brevenal is necessary (Figure 4). For detailed comparison with the natural product, the ${ }^{1} \mathrm{H}$ and ${ }^{13} \mathrm{C}$ NMR data of synthetic 1 were carefully assigned on the basis of extensive 2D NMR experiments, and the results are summarized in Tables 3 and 4 and Figure 5. The ${ }^{1} \mathrm{H}$ and ${ }^{13} \mathrm{C}$ NMR chemical shifts in the left-hand region of synthetic 1 matched very closely those reported for the natural brevenal. In contrast, there were subtly distinct discrepancies of the chemical shifts in the DE ring region. Particularly, the observed chemical shifts around the C26 tertiary alcohol of 1 significantly deviated from those for the natural product, suggesting that an error (s) may exist somewhere around the E ring. COSY, HSQC, and HMBC correlations of the synthetic sample completely reproduced those of the authentic sample. However, a series of intense cross-peaks were observed between $26-\mathrm{Me} / 27-\mathrm{H}$ and $26-\mathrm{Me} / 28-\mathrm{H}_{2}$ in the NOESY spectrum of synthetic 1 (Figure 5), whereas no such NOESY correlations have been reported for naturally occurring brevenal. ${ }^{8 \mathrm{~b}}$ These NMR variations prompted us to propose the stereochemical inversion of the $\mathrm{C} 26$ tertiary alcohol within $\mathbf{1}$, giving the revised structure $\mathbf{2}$ for brevenal.

The revised structure $\mathbf{2}$ is also supported by the postulated biosynthetic pathway for laddershaped polycyclic ether marine natural products (i.e., a cascade of polyepoxide cyclization) proposed by Shimizu and Nakanishi, independently (Figure 6). 7,43,44 The stereochemistry at 
C26 of brevenal would be epimeric to the proposed structure 1, provided that a similar biosynthetic route is applicable to brevenal (Figure 6).

\section{Total Synthesis of Revised Structure and the Absolute Configuration of Brevenal}

To confirm our postulated idea, we turned to the synthesis of the C26 epimer $\mathbf{2}$ of the originally proposed structure 1. Starting with an intermediate $\mathbf{2 5}$ in the synthesis of $\mathbf{7}$ (see Scheme 3), the requisite DE ring fragment 57 (26-epi-7) was prepared as summarized in Scheme 8. WackerTsuji reaction 45 of the terminal olefin within 25 using the $\mathrm{PdCl}_{2} / \mathrm{Cu}(\mathrm{OAc})_{2}$ system 46 provided methyl ketone $\mathbf{5 8}$ in $92 \%$ yield. Removal of the TBS group from $\mathbf{5 8}$ followed by incorporation of a $\beta$-alkoxyacrylate unit to the resulting secondary alcohol produced 59 in high overall yield. Reductive cyclization of $\mathbf{5 9}$ with $\mathrm{SmI}_{2}$ (MeOH/THF, room temperature) proceeded smoothly to form the seven-membered ether ring with the desired stereochemistry at $\mathrm{C} 26$, providing a mixture of $\gamma$-lactone $\mathbf{6 0}$ and hydroxy ester $\mathbf{6 1}$ in $57 \%$ and $37 \%$ yield, respectively. ${ }^{26}$ The C26 and $\mathrm{C} 27$ stereochemistries of $\mathbf{6 0}$ were confirmed by NOE experiments as shown. Each of these compounds was cleanly reduced with lithium aluminum hydride (THF, $0^{\circ} \mathrm{C}$ ) to yield the same diol 62 in high yield. After protection as the bis-TBS ether, selective cleavage of the primary TBS ether under acidic conditions provided alcohol 63 in $90 \%$ yield for the two steps. Oxidation with $\mathrm{SO}_{3} \bullet$ pyridine/DMSO followed by Wittig methylenation of the resulting aldehyde led to $\mathbf{6 4}$ (94\% yield, two steps), which was subsequently transformed to the DE ring fragment $\mathbf{5 7}$ following a similar sequence described for the conversion of $\mathbf{3 1}$ to $\mathbf{7}$ (see, Scheme 4).

Convergent union of the DE ring fragment 57 and the $A B$ ring enol phosphate 6 and subsequent elaboration of the resulting cross-coupled product $\mathbf{6 7}$ could be performed in much the same way as that used to reach $\mathbf{1}$ and proceeded in similar yields, thus completing the total synthesis of the revised structure 2 for brevenal (Scheme 9). To our delight, the ${ }^{1} \mathrm{H}$ and ${ }^{13} \mathrm{C}$ NMR spectra and high-resolution mass spectrum of synthetic 2 were completely identical with those of the natural product, culminating in a conclusion that the $\mathrm{C} 26$ epimer of the originally proposed structure is the correct structure of brevenal. In addition, synthetic brevenal 2 exhibited specific rotation, $[\alpha]_{\mathrm{D}} 27-33.5$ ( $c 0.27$, benzene), which matched the value $[\alpha]_{\mathrm{D}}{ }^{27}-32.3(c 0.27$, benzene) for the natural product; thus, the absolute configuration of brevenal was unequivocally determined to be shown as structure $\mathbf{2}$.

\section{Conclusion}

We accomplished the first total synthesis of the proposed structure $\mathbf{1}$ of brevenal. The key features of our synthesis include a convergent assembly of the pentacyclic polyether skeleton by using the Suzuki-Miyaura coupling-based strategy and a stereoselective construction of the left-hand multi-substituted $(E, E)$-diene system by the CuTC-promoted modified Stille coupling. The ${ }^{1} \mathrm{H}$ and ${ }^{13} \mathrm{C}$ NMR spectra of synthetic 1 did not match those for the natural product. Detailed NMR comparison of the synthetic material with the natural substance and the proposed biosynthesis of ladder-shaped polycyclic ether natural products led us to propose a revised structure $\mathbf{2}$, the $\mathrm{C} 26$-epimer of $\mathbf{1}$. In the event, the revised structure was validated through total synthesis, which also led to determination of the absolute configuration. This study demonstrates the important role of stereoselective total synthesis in structure determination of complex natural products. ${ }^{47}$ Moreover, the highly convergent nature of the present synthesis will allow divergent total synthesis of structural analogues for more detailed structure-activity relationship studies of this intriguing natural product. Further studies along this line are currently underway and will be reported in due course.

\section{Supplementary Material}

Refer to Web version on PubMed Central for supplementary material. 


\section{Acknowledgment}

We thank Mr. Ryuichi Watanabe (Tohoku University) for NMR measurements, and Dr. Thomas Schuster and Dr. Sophie Michelliza (UNCW) for their technical expertise. This work was financially supported in part by the Naito Foundation and a Grant-in-Aid for Scientific Research from the Ministry of Education, Culture, Sports, Science and Technology, Japan (MEXT) and the Japan Society for the Promotion of Science (JSPS). A postdoctoral fellowship for H.F. and a research fellowship for M.E. from JSPS are acknowledged.

\section{References}

1. For reviews on marine polycyclic ethers, see:(a) Yasumoto T, Murata M. Chem. Rev 1993;93:18971909. (b) Murata M, Yasumoto T. Nat. Prod. Rep 2000:293-314. [PubMed: 10888014] (c) Yasumoto T. Chem. Rec 2001;3:228-242. [PubMed: 11895121]

2. For recent comprehensive reviews on total synthesis of polycyclic ethers, see: (1) Nakata T. Chem. Rev 2005;105:4314-4347. [PubMed: 16351046] (b) Inoue M. Chem. Rev 2005;105:4379-4405. [PubMed: 16351048]

3. Lin Y-Y, Risk M, Ray SM, Van Engen D, Clardy J, Golik J, James JC, Nakanishi K. J. Am. Chem. Soc 1981;103:6773-6775.

4. Shimizu Y, Chou H-N, Bando H, Van Duyne G, Clardy JC. J. Am. Chem. Soc 1986;108:514-515.

5. Poli MA, Mende TJ, Baden DG. Mol. Pharmacol 1986;30:129-135. [PubMed: 2426567]

6. For recent reviews, see: (a) Baden DG, Bourdelais AJ, Jacocks H, Michelliza S, Naar J. Environ. Health Perspect 2005;113:621-625. [PubMed: 15866774] (b) Kirkpatrick B, Fleming LE, Squicciarini D, Backer LC, Clark R, Abraham W, Bentson J, Cheng YS, Johnson D, Pierce R, Zais J, Bossart GD, Baden DG. Harmful Algae 2004;3:99-115.

7. Prasad AVK, Shimizu Y. J. Am. Chem. Soc 1989;111:6476-6477.

8. (a) Bourdelais AJ, Campbell S, Jacocks H, Naar J, Wright JLC, Carsi J, Baden DG. Cell. Mol. Neurobiol 2004;24:553-563. [PubMed: 15233378] (b) Bourdelais AJ, Jacocks HM, Wright JLC, Bigwarfe PM Jr. Baden DG. J. Nat. Prod 2005;68:2-6. [PubMed: 15679307]

9. Sayer A, Hu Q, Bourdelais AJ, Baden DG, Gilson JE. Arch. Toxicol 2005;79:683-688. [PubMed: 15986201]

10. Abraham WM, Bourdelais AJ, Sabater JR, Ahmed A, Lee TA, Serebriakov I, Baden DG. Am. J. Respir. Crit. Care Med 2005;171:26-34. [PubMed: 15447946]

11. For a preliminary communication, see: Fuwa H, Ebine M, Sasaki M. J. Am. Chem. Soc 2006;128:9648-9650. [PubMed: 16866516]

12. (a) Nicolaou KC, Reddy KR, Skokotas G, Sato F, Xiao X-Y. J. Am. Chem. Soc 1992;114:7935-7936. (b) Nicolaou KC, Reddy KR, Skokotas G, Sato F, Xiao X-Y, Hwang C-K. J. Am. Chem. Soc 1993;115:3558-3575.

13. For recent reviews, see: (a) Nicolaou KC, Bulger PG, Sarlah D. Angew. Chem., Int. Ed 2005;44:44424489. (b) Espinet P, Echavarren AE. Angew. Chem., Int. Ed 2004;43:4704-4734.(c)MitchellTCde MeijereADiederichFMetal-catalyzed Cross-coupling Reactions2004125162WileyVCHWeinheim2nd ed. (d) Farina V, Krishnamurthy V, Scott WJ. Org. React 1997;50:1-652.

14. For reviews on Suzuki-Miyaura coupling, see: (a) Suzuki A, Miyaura N. Chem. Rev 1995;95:24572483. (b) Chemler SR, Trauner D, Danishefsky SJ. Angew. Chem., Int. Ed 2001;40:4544-4568.

15. (a) Sasaki M, Fuwa H, Inoue M, Tachibana K. Tetrahedron Lett 1998;39:9027-9030. (b) Sasaki M, Fuwa H, Ishikawa M, Tachibana K. Org. Lett 1999;1:1075-1077. (c) Sasaki M, Ishikawa M, Fuwa H, Tachibana K. Tetrahedron 2002;58:1889-1911. (d) Sasaki M, Fuwa H. Synlett 2004:1851-1874.

16. (a) Fuwa H, Sasaki M, Satake M, Tachibana K. Org. Lett 2002;4:2981-2984. [PubMed: 12182604] (b) Fuwa H, Kainuma N, Tachibana K, Sasaki M. J. Am. Chem. Soc 2002;124:14983-14992. [PubMed: 12475341] (c) Tsukano C, Sasaki M. J. Am. Chem. Soc 2003;125:14294-14295. [PubMed: 14624575] (d) Tsukano C, Ebine M, Sasaki M. J. Am. Chem. Soc 2005;127:4326-4335. [PubMed: 15783214]

17. Evans DA, Bartroli J, Shih TL. J. Am. Chem. Soc 1981;103:2127-2129.

18. Prashad M, Har P, Kim H-Y, Repic O. Tetrahedron Lett 1998;39:7067-7070. 
19. (a) Johansson R, Samuelsson B. J. Chem. Soc., Chem. Commun 1984:201-202. (b) Johansson R, Samuelsson B. J. Chem. Soc., Perkin Trans. 1 1984:2371-2374.

20. Uehara H, Oishi T, Inoue M, Shoji M, Nagumo Y, Kosaka M, Le Brazidec J-M, Hirama M. Tetrahedron 2002;58:6493-6512.

21. Yamaguchi M, Inanaga J, Hirata K, Sasaki H, Katsuki T. Bull. Chem. Soc. Jpn 1979;52:1989-1993. 22. Nicolaou KC, Shi G-Q, Gunzner JL, Gärtner P, Yang Z. J. Am. Chem. Soc 1997;119:5467-5468.

23. Kadota I, Ohno A, Matsukawa Y, Yamamoto Y. Tetrahedron Lett 1998;39:6373-6776.

24. Mori Y, Yaegashi K, Furukawa H. J. Am. Chem. Soc 1996;118:8158-8159.

25. Kotsuki H, Kadota I, Masamitsu O. Tetrahedron Lett 1990;31:4609-4612.

26. (a) Hori N, Matsukura H, Matsuo G, Nakata T. Tetrahedron Lett 1999;40:2811-2814. (b) Hori N, Matsukura H, Nakata T. Org. Lett 1999;1:1099-1101. (c) Matsuo G, Hori N, Nakata T. Tetrahedron Lett 1999;40:8859-8862. (d) Hori N, Matsukura H, Matsuo G, Nakata T. Tetrahedron 2002;58:18531864.

27. Ley SV, Normann J, Griffith WP, Marsden SP. Synthesis 1994:639-666.

28. The carbon numbering of all compounds in this paper corresponds to that of brevenal.

29. Sasaki M, Ebine M, Takagi H, Takakura H, Shida T, Satake M, Oshima Y, Igarashi T, Yasumoto T. Org. Lett 2004;6:1501-1504. [PubMed: 15101777]

30. (a) Nicolaou KC, Prasad CVC, Hwang C-K, Duggan ME, Veale CA. J. Am. Chem. Soc 1989;111:5321-5330. (b) Fuwa H, Sasaki M, Tachibana K. Tetrahedron Lett 2000;41:8371-8375.

(c) Fuwa H, Sasaki M, Tachibana K. Tetrahedron 2001;57:3019-3033.

31. Farina V, Krishnan B. J. Am. Chem. Soc 1991;113:9585-9595.

32. Farina V, Kapadia S, Krishnan B, Wang C, Liebeskind LS. J. Org. Chem 1994;59:5905-5911.

33. Allred GD, Liebeskind LS. J. Am. Chem. Soc 1996;118:2748-2749.

34. (a) Freeman PK, Hutchinson LL. J. Org. Chem 1980;45:1924-1930. (b) Ireland RE, Smith MG. J. Am. Chem. Soc 1988;110:854-860.

35. Higashibayashi S, Shinko K, Ishizu T, Hashimoto K, Shirahama H, Nakata M. Synlett 2000:13061308.

36. The reaction mixture was stirred at room temperature overnight (ca. $13 \mathrm{~h})$. Since, at this point, ca. $50 \%$ of the starting material $\mathbf{4 8}$ remained unreacted and a small amount of diol $\mathbf{S 8}$ was observed by TLC analysis, the reaction was quenched. After separation of $\mathbf{4 8 , 4 9 , ~ S 8 , ~ a n d ~ S 7 ~ b y ~ f l a s h ~}$ chromatography, recycling of the recovered $\mathbf{4 8}$ (three times) provided $\mathbf{4 9}(78 \%), \mathbf{S 8}(8 \%)$ and $\mathbf{S 7}$ $(12 \%)$.

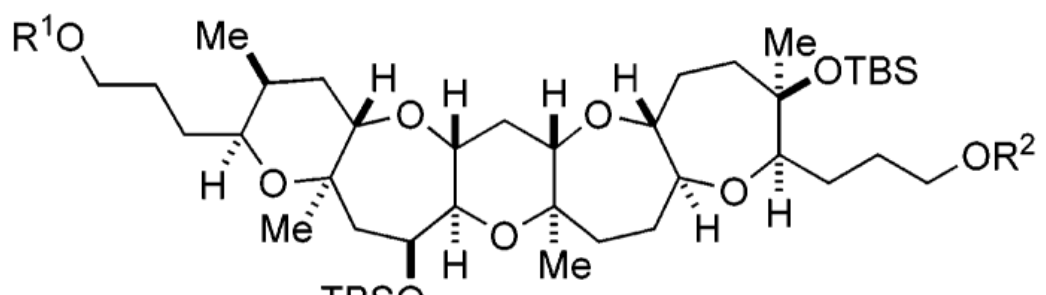
TBSO
48: $R^{1}=$ TBDPS, $R^{2}=$ TBS
49: $R^{1}=H, R^{2}=T B S$
S8: $R^{1}=R^{2}=H$
S7: $\mathrm{R}^{1}=$ TBDPS, $\mathrm{R}^{2}=\mathrm{H}$ 
37. Dess DB, Martin JC. J. Org. Chem 1983;48:4155-4156.

38. (a) Ohira S. Synth. Commun 1989;19:561-564. (b) Müller S, Liepold B, Roth GJ, Bestmann HJ. Synlett 1996:521-522.

39. (a) Fleming I, Newton TW, Roessler F. J. Chem. Soc. Perkin Trans 1 1981:2527-2532. (b) Zakarian A, Batch A, Holton RA. J. Am. Chem. Soc 2003;125:7822-7824. [PubMed: 12822999]

40. Stamos DP, Taylor AG, Kishi Y. Tetrahedron Lett 1996;37:8647-8650.

41. We initially attempted the Stille coupling of TBDPS-protected vinyl stannane $\mathbf{5 a}$ with vinyl iodide 3; however, the desired cross-coupled product was obtained in only poor yield (22\%).

42. (a) Noyori R, Nishida I, Sakata J, Nishizawa M. J. Am. Chem. Soc 1980;102:1223-1225. (b) Sheidt KA, Chen H, Follows BC, Chemler SR, Coffey DS, Roush WR. J. Org. Chem 1998;63:6436-6437.

43. (a) Nakanishi K. Toxicon 1985;23:473-479. [PubMed: 3895583]Shimizu, Y. Natural Toxins: Animal, Plant and Microbial. Harris, JB., editor. Clarendon Press; Oxford: 1986. p. 115-125. (c) Lee MS, Repeta DJ, Nakanishi K. J. Am. Chem. Soc 1986;108:7855-7856. (d) Chou H-N, Shimizu Y. J. Am. Chem. Soc 1987;109:2184-2185.Lee MS, Qin G, Nakanishi K, Zagorski MG. J. Am. Chem. Soc 1989;111:6234-6241. (e) Townsend CA, Basak A. Tetrahedron 1991;47:2591-2602. (f) Gallimore AR, Spencer JB. Angew. Chem., Int. Ed 2006;45:4406-4413.

44. For recent reviews on biomimetic synthesis of polycyclic ethers, see: (a) Fujiwara K, Murai A. Bull. Chem. Soc. Jpn 2004;77:2129-2146. (b) Valentine JC, McDonald FE. Synlett 2006:1816-1828.

45. For a review, see: Tsuji J. Synthesis 1984:369-384.

46. Smith AB III, Cho YS, Friestad GK. Tetrahedron Lett 1998;39:8765-8768.

47. For recent reviews, see: (a) Weinreb SM. Acc. Chem. Res 2003;36:59-65. [PubMed: 12534305] (b) Nicolaou KC, Snyder SA. Angew. Chem., Int. Ed 2005;44:1012-1044. 


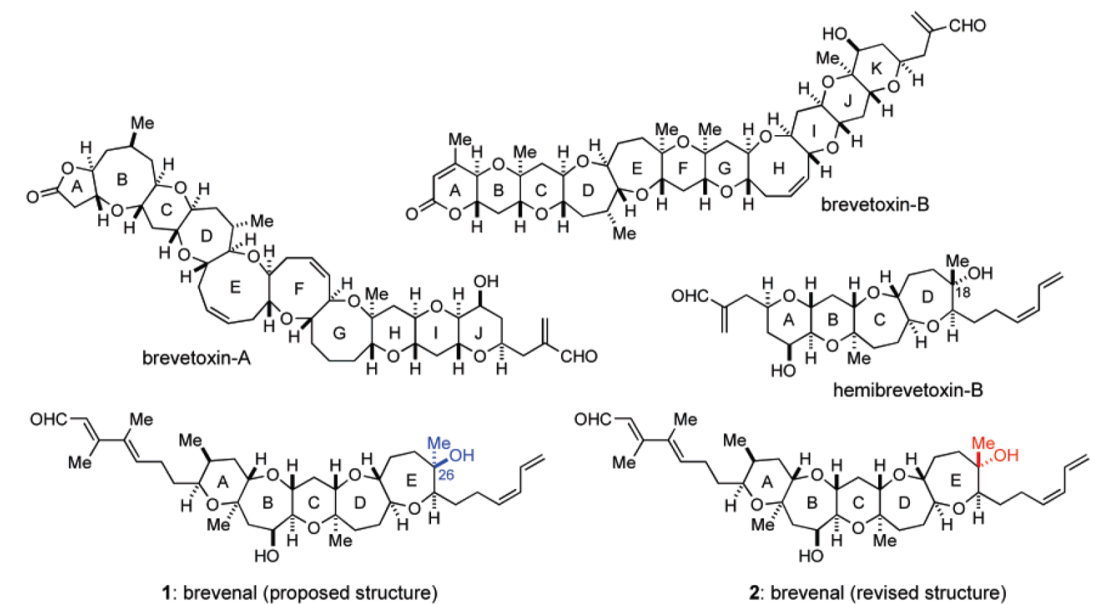

Figure 1.

Structures of brevetoxin-A, brevetoxin-B, hemibrevetoxin-B, and brevenal (proposed structure $\mathbf{1}$ and revised structure $\mathbf{2}$ ). 


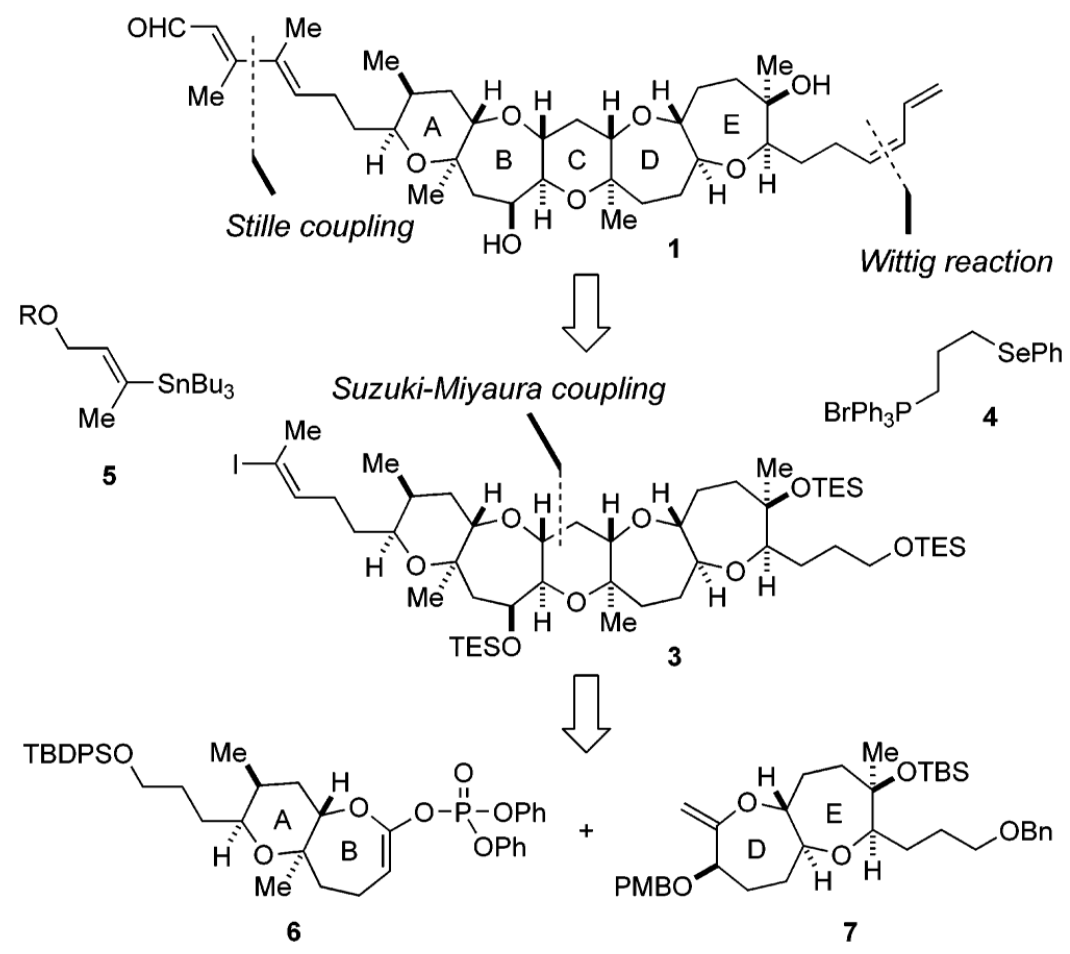

Scheme 1.

Retrosynthetic Analysis 


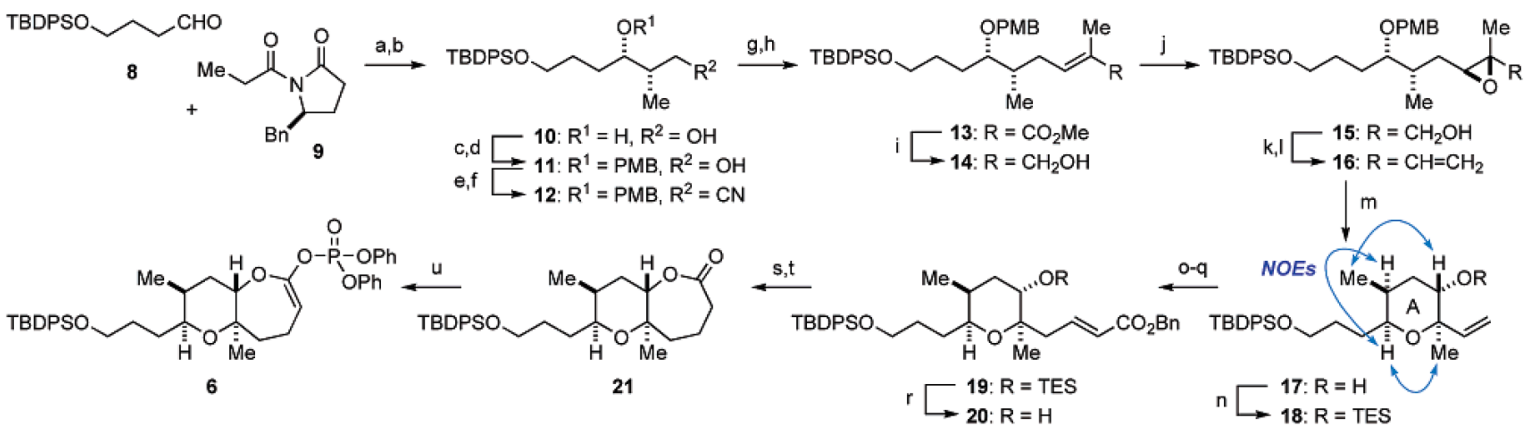

Scheme 2.

Synthesis of the AB Ring Fragment ${ }^{a}$

${ }^{a}$ Reagents and conditions: (a) $n$ - $\mathrm{Bu}_{2} \mathrm{BOTf}, \mathrm{Et}_{3} \mathrm{~N}, \mathrm{CH}_{2} \mathrm{Cl}_{2},-78 \rightarrow 0{ }^{\circ} \mathrm{C}$; (b) $\mathrm{NaBH}_{4}$, THF/

$\mathrm{H}_{2} \mathrm{O}$, rt, $90 \%$ (two steps); (c) $p-\mathrm{MeOC}_{6} \mathrm{H}_{4} \mathrm{CH}(\mathrm{OMe})_{2}, \mathrm{PPTS}, \mathrm{CH}_{2} \mathrm{Cl}_{2}$, rt; (d) DIBALH, $\mathrm{CH}_{2} \mathrm{Cl}_{2},-78 \rightarrow-40{ }^{\circ} \mathrm{C}, 94 \%$ (two steps); (e) $\mathrm{MsCl}_{1} \mathrm{Et}_{3} \mathrm{~N}, \mathrm{CH}_{2} \mathrm{Cl}_{2}, 0{ }^{\circ} \mathrm{C}$; (f) $\mathrm{NaCN}$, DMSO, $60{ }^{\circ} \mathrm{C}, 96 \%$ (two steps); (g) DIBALH, $\mathrm{CH}_{2} \mathrm{Cl}_{2},-78^{\circ} \mathrm{C}, 90 \%$; (h) $\mathrm{Ph} 3{ }_{3} \mathrm{P}=\mathrm{C}(\mathrm{Me}) \mathrm{CO}_{2} \mathrm{Et}$, toluene, $100{ }^{\circ} \mathrm{C}$, 97\%; (i) DIBALH, $\mathrm{CH}_{2} \mathrm{Cl}_{2},-78{ }^{\circ} \mathrm{C}$, quant.; (j) (+)-DET, Ti(Oi-Pr) $)_{4}, t$-BuOOH, $\mathrm{CH}_{2} \mathrm{Cl}_{2},-40{ }^{\circ} \mathrm{C}, 88 \%$; (k) $\mathrm{SO}_{3} \bullet$ pyridine, $\mathrm{Et}_{3} \mathrm{~N}, \mathrm{DMSO} / \mathrm{CH}_{2} \mathrm{Cl}_{2}(1: 1), 0^{\circ} \mathrm{C}$; (l) $\mathrm{Ph}_{3} \mathrm{P}^{+} \mathrm{CH}_{3} \mathrm{Br}^{-}$, NaHMDS, THF, $0{ }^{\circ} \mathrm{C}$, $90 \%$ (two steps); (m) DDQ, $\mathrm{CH}_{2} \mathrm{Cl}_{2} / \mathrm{H}_{2} \mathrm{O}$ (20:1), rt; (n) TESOTf, 2,6-lutidine, $\mathrm{CH}_{2} \mathrm{Cl}_{2}, 0{ }^{\circ} \mathrm{C}, 89 \%$ (two steps); (o) (Sia) ${ }_{2} \mathrm{BH}, \mathrm{THF}, 0{ }^{\circ} \mathrm{C}$; then aq $\mathrm{NaHCO}_{3}, 30 \% \mathrm{H}_{2} \mathrm{O}_{2}, \mathrm{rt}, 92 \%$; (p) $\mathrm{SO}_{3} \bullet$ pyridine, Et $3 \mathrm{~N}$, DMSO/CH $\mathrm{Cl}_{2}(1: 1), 0{ }^{\circ} \mathrm{C}$; (q) $\mathrm{Ph}_{3} \mathrm{P}=\mathrm{CHCO}_{2} \mathrm{Bn}$, toluene, $60{ }^{\circ} \mathrm{C}, 86 \%$ (two steps); (r) $1 \mathrm{M} \mathrm{HCl}$, THF, rt, $95 \%$; (s) $\mathrm{H}_{2}, 20 \%$ $\mathrm{Pd}(\mathrm{OH})_{2} / \mathrm{C}, \mathrm{THF} / \mathrm{MeOH}(2: 1)$, rt, $90 \%$; (t) $2,4,6-\mathrm{Cl}_{3} \mathrm{C}_{6} \mathrm{H}_{2} \mathrm{COCl}, \mathrm{Et} 3 \mathrm{~N}, \mathrm{THF}, 0{ }^{\circ} \mathrm{C} \rightarrow \mathrm{rt}$; then DMAP, toluene, $110{ }^{\circ} \mathrm{C}, 98 \%$; (u) KHMDS, $(\mathrm{PhO}){ }_{2} \mathrm{P}(\mathrm{O}) \mathrm{Cl}$, HMPA, THF, $-78{ }^{\circ} \mathrm{C}, 96 \%$. 


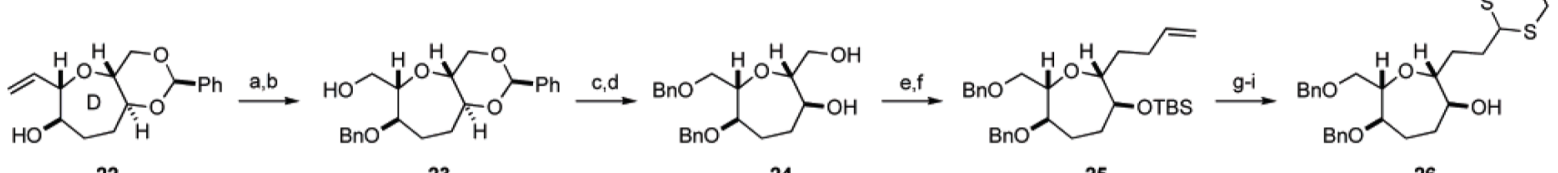

22

23

24

25

26

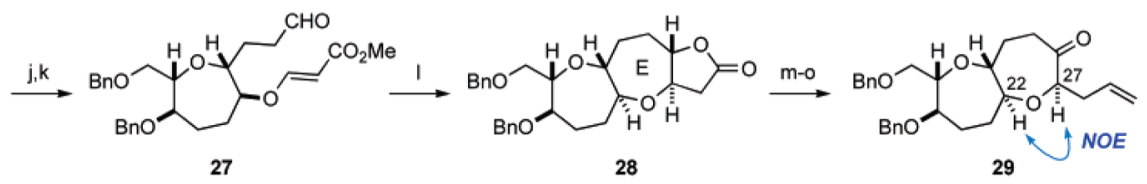

Scheme 3.

Synthesis of Ketone $\mathbf{2 9}^{\mathrm{a}}$

${ }^{a}$ Reagents and conditions: (a) $\mathrm{KO} t-\mathrm{Bu}, \mathrm{BnBr}, n-\mathrm{Bu} 4 \mathrm{NI}$, THF, rt; (b) $\mathrm{O}_{3}, \mathrm{CH}_{2} \mathrm{Cl}_{2} / \mathrm{MeOH}(1: 1)$, $-78{ }^{\circ} \mathrm{C}$; then $\mathrm{NaBH}_{4}, 0{ }^{\circ} \mathrm{C}, 96 \%$ (two steps); (c) $\mathrm{NaH}, \mathrm{BnBr}$, THF/DMF (1:1), rt; (d) CSA, $\mathrm{MeOH} / \mathrm{CH}_{2} \mathrm{Cl}_{2}$ (10:1), rt, quant. (two steps); (e) $\mathrm{Tf}{ }_{2} \mathrm{O}, 2$,6-lutidine, $\mathrm{CH}_{2} \mathrm{Cl}_{2},-78{ }^{\circ} \mathrm{C}$; then TBSOTf, $0{ }^{\circ} \mathrm{C}$; (f) allylMgBr, $\mathrm{CuBr}, \mathrm{Et}_{2} \mathrm{O}, 0{ }^{\circ} \mathrm{C}, 85 \%$ (two steps); (g) $\mathrm{OsO}_{4}, \mathrm{NMO}$, THF/ $\mathrm{H}_{2} \mathrm{O}$ (7:1), rt; then $\mathrm{NaIO}_{4}$, rt; (h) $\mathrm{HS}\left(\mathrm{CH}_{2}\right)_{3} \mathrm{SH}, \mathrm{BF}_{3} \cdot \mathrm{OEt}_{2}, \mathrm{CH}_{2} \mathrm{Cl}_{2},-78 \rightarrow 0{ }^{\circ} \mathrm{C}$; (i) TBAF, THF, rt, $88 \%$ (three steps); (j) methyl propiolate, $\mathrm{NMM}, \mathrm{CH}_{2} \mathrm{Cl}_{2}$, rt; (k) MeI, $\mathrm{NaHCO}_{3}, \mathrm{MeCN} /$ $\mathrm{H}_{2} \mathrm{O}$ (4:1), rt, $99 \%$ (two steps); (1) $\mathrm{SmI}_{2}, \mathrm{MeOH}$, THF, rt; then $p-\mathrm{TsOH} \cdot \mathrm{H}_{2} \mathrm{O}$, toluene, $80{ }^{\circ} \mathrm{C}$, $84 \%$ (two steps); (m) DIBALH, $\mathrm{CH}_{2} \mathrm{Cl}_{2},-78^{\circ} \mathrm{C}$; (n) $\mathrm{Ph}_{3} \mathrm{P}^{+} \mathrm{CH}_{3} \mathrm{Br}^{-}$, NaHMDS, THF, $0{ }^{\circ} \mathrm{C} \rightarrow$ rt, 94\% (two steps); (o) TPAP, NMO, $4 \AA$ molecular sieves, $\mathrm{CH}_{2} \mathrm{Cl}_{2}$, rt, $97 \%$. 

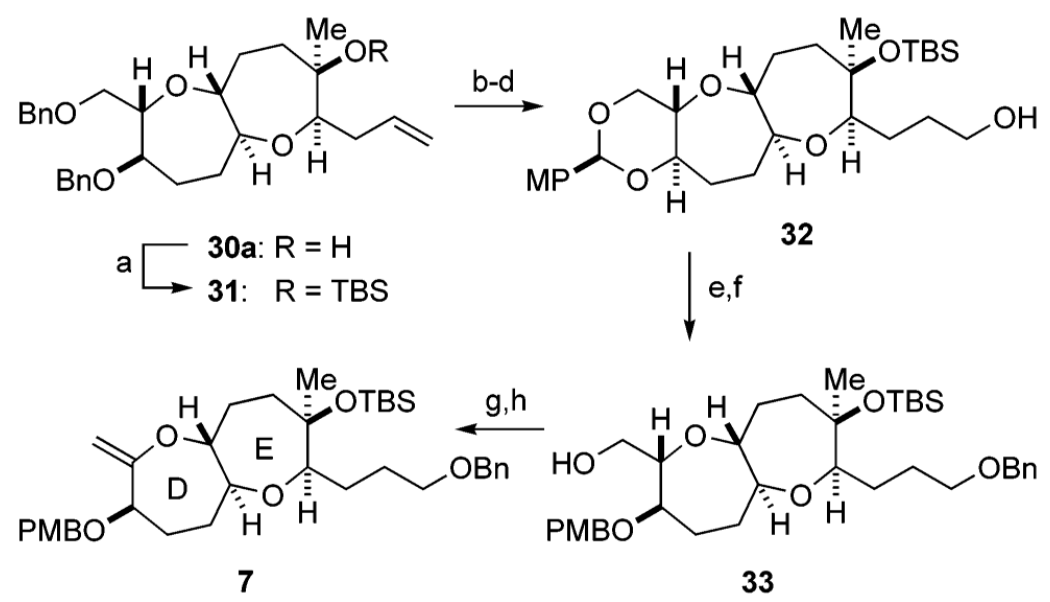

Scheme 4.

Synthesis of the DE Ring Fragment $7^{a}$

${ }^{a}$ Reagents and conditions: (a) TBSOTf, $\mathrm{Et}_{3} \mathrm{~N}, \mathrm{CH}_{2} \mathrm{Cl}_{2}$, rt, quant.; (b) 9-BBN, THF, rt; then aq $\mathrm{NaHCO}_{3}, 30 \% \mathrm{H}_{2} \mathrm{O}_{2}$, rt; (c) $\mathrm{H}_{2}, 20 \% \mathrm{Pd}(\mathrm{OH})_{2} / \mathrm{C}, \mathrm{MeOH}, \mathrm{rt}$; (d) $p$ - $\mathrm{MeOC}_{6} \mathrm{H}_{4} \mathrm{CH}(\mathrm{OMe})_{2}$, PPTS, $\mathrm{CH}_{2} \mathrm{Cl}_{2}$, rt, $70 \%$ (three steps); (e) $\mathrm{KO} t$-Bu, BnBr, $n$-Bu $\mathrm{Bu}_{4}$, THF, rt; (f) DIBALH, $\mathrm{CH}_{2} \mathrm{Cl}_{2},-78 \rightarrow 0{ }^{\circ} \mathrm{C}, 87 \%$ (two steps); (g) $\mathrm{I}_{2}, \mathrm{PPh}_{3}$, imidazole, benzene, rt; (h) $\mathrm{KO} t$ - $\mathrm{Bu}, \mathrm{THF}$, $0{ }^{\circ} \mathrm{C}, 92 \%$ (two steps). 

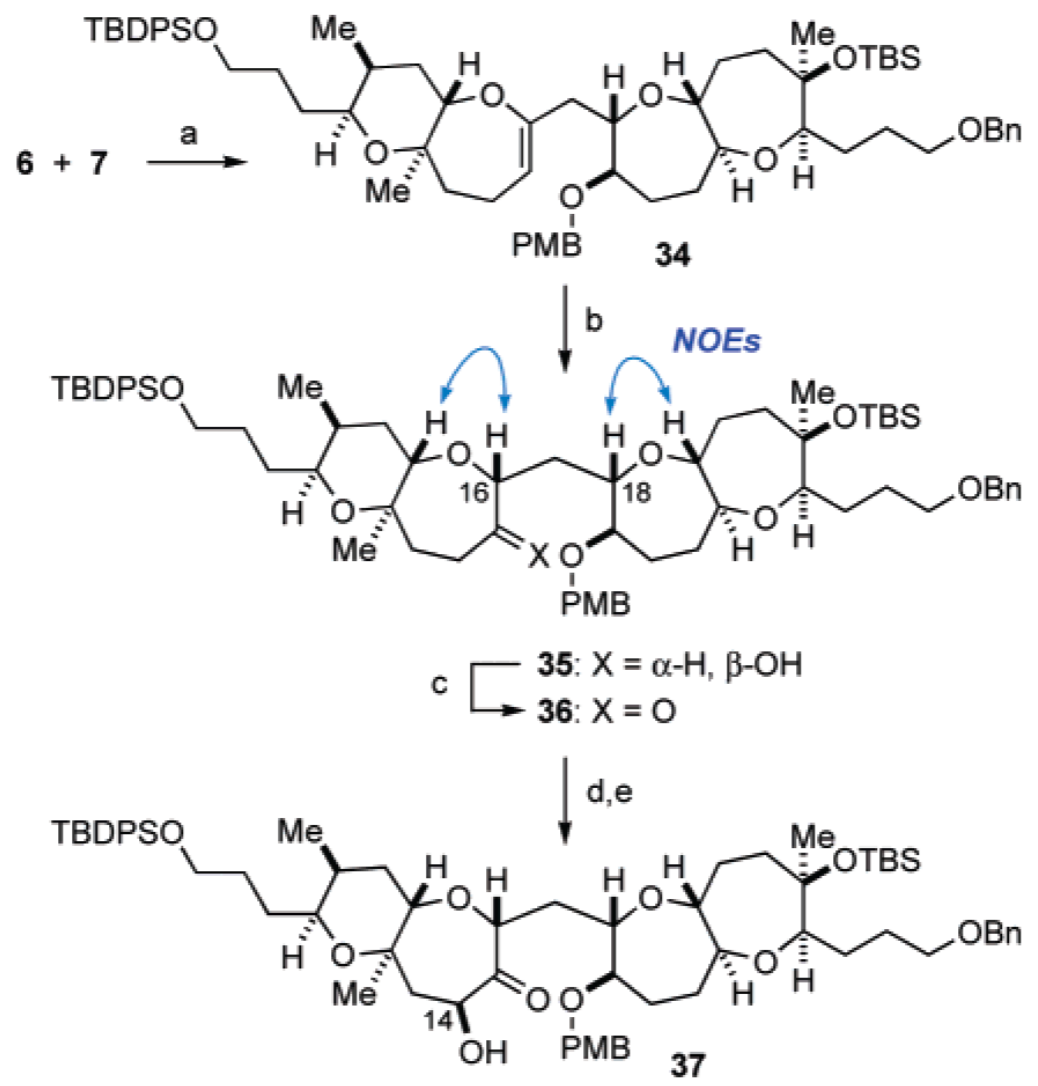

Scheme 5.

Synthesis of $\alpha$-Hydroxy Ketone $\mathbf{3 7}^{a}$

${ }^{a}$ Reagents and conditions: (a) 7, 9-BBN, THF, rt; aq $\mathrm{Cs}_{2} \mathrm{CO}_{3}, 6$, $\mathrm{Pd}\left(\mathrm{PPh}_{3}\right)_{4}$, DMF, $50{ }^{\circ} \mathrm{C}$; (b) $\mathrm{BH}_{3} \cdot \mathrm{SMe}_{2}$, THF, rt; then aq $\mathrm{NaHCO}_{3}, 30 \% \mathrm{H}_{2} \mathrm{O}_{2}, \mathrm{rt}, 84 \%$ (two steps); (c) TPAP, NMO, $4 \AA$ molecular sieves, $\mathrm{CH}_{2} \mathrm{Cl}_{2}, 0{ }^{\circ} \mathrm{C}, 98 \%$; (d) LiHMDS, TMSCl, $\mathrm{Et}_{3} \mathrm{~N}, \mathrm{THF},-78{ }^{\circ} \mathrm{C}$; (e) $\mathrm{OsO}_{4}$, $\mathrm{NMO}, \mathrm{THF} / \mathrm{H}_{2} \mathrm{O}(4: 1), \mathrm{rt}, 87 \%$ (two steps). 

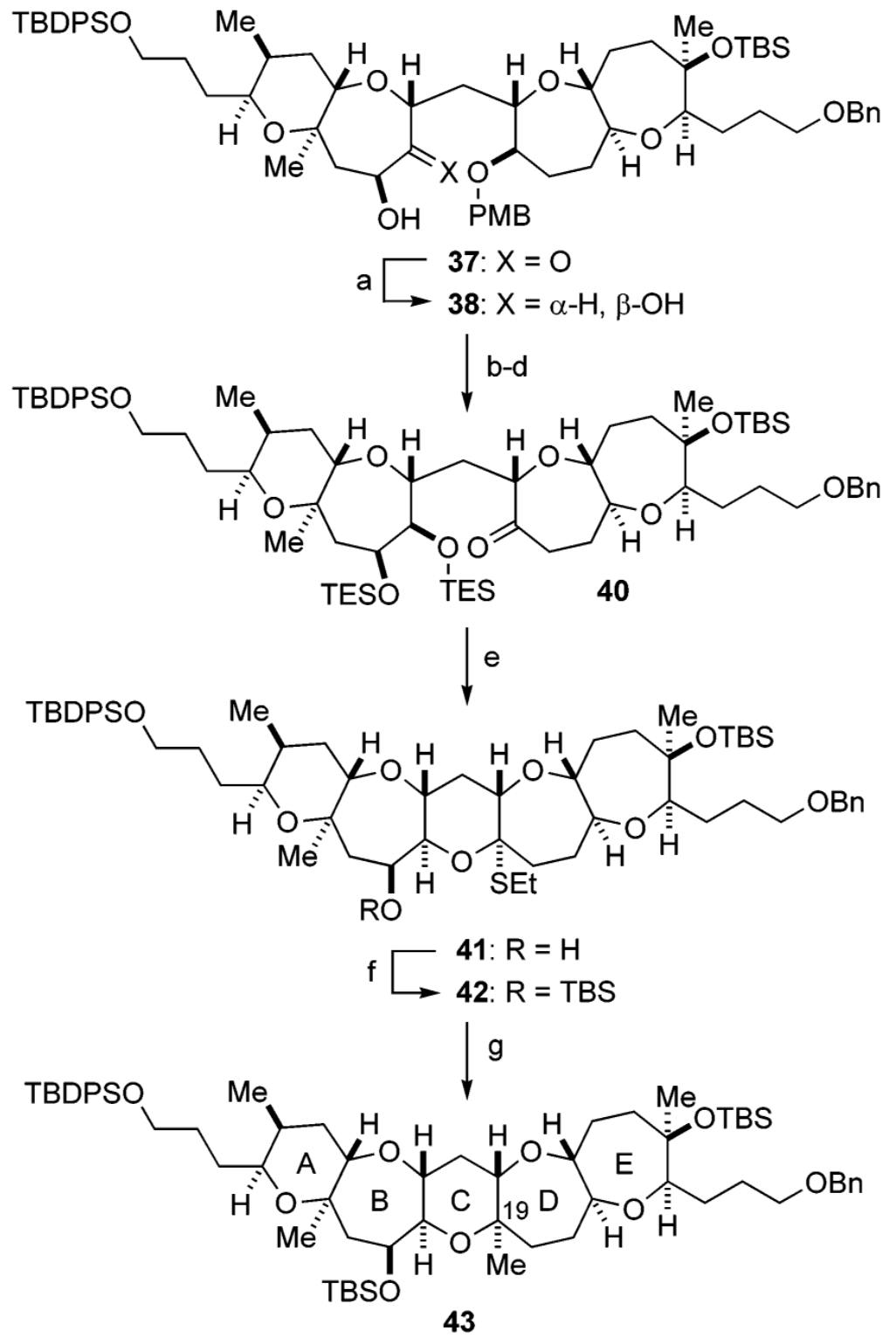

Scheme 6.

Synthesis of the Pentacyclic Polyether Core ${ }^{a}$

${ }^{a}$ Reagents and conditions: (a) DIBALH, THF, $-78{ }^{\circ} \mathrm{C}, 76 \%$ (+diastereomer, $7 \%$; recovered 37, 12\%); (b) TESOTf, $\mathrm{Et}_{3} \mathrm{~N}, \mathrm{CH}_{2} \mathrm{Cl}_{2}, 0^{\circ} \mathrm{C}$; (c) DDQ, $\mathrm{CH}_{2} \mathrm{Cl}_{2} / \mathrm{pH} 7$ phosphate buffer, rt; (d) TPAP, NMO, $4 \AA$ A molecular sieves, $\mathrm{CH}_{2} \mathrm{Cl}_{2}$, rt, $88 \%$ (three steps); (e) EtSH, $\mathrm{Zn}(\mathrm{OTf})_{2}$, THF, rt, 79\%; (f) TBSOTf, $\mathrm{Et}_{3} \mathrm{~N}, \mathrm{CH}_{2} \mathrm{Cl}_{2}, 0{ }^{\circ} \mathrm{C}, 97 \%$; (g) $m \mathrm{CPBA}, \mathrm{CH}_{2} \mathrm{Cl}_{2},-78{ }^{\circ} \mathrm{C}$; then $\mathrm{Me}_{3} \mathrm{Al}$ (excess), $-78 \rightarrow 0{ }^{\circ} \mathrm{C}, 92 \%$. 


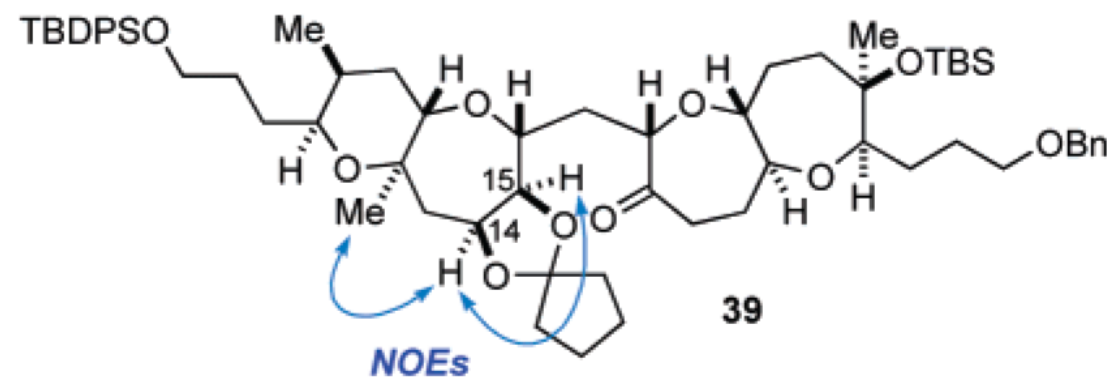

Figure 2.

Stereochemical confirmation of cis-diol $\mathbf{3 8}$. 


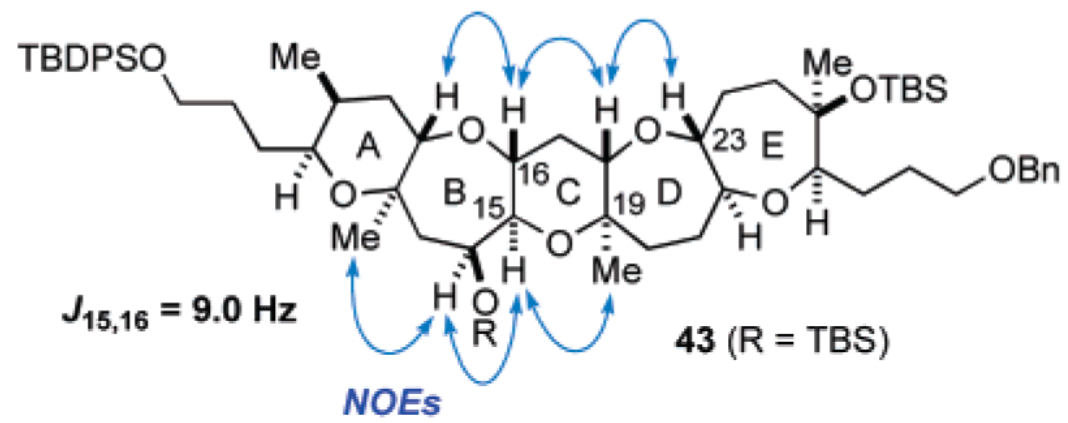

Figure 3.

Stereochemical confirmation of pentacyclic polyether 43 . 


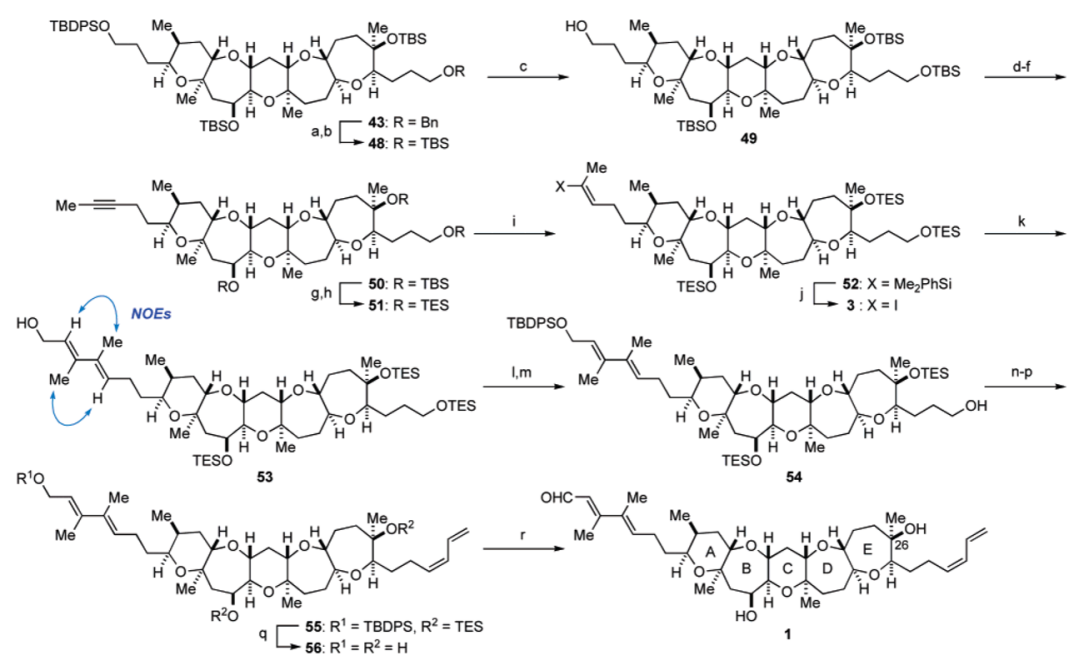

Scheme 7.

Total Synthesis of the Proposed Structure 1 for Brevenal ${ }^{a}$

${ }^{a}$ Reagents and conditions: (a) LiDBB, THF, $-78{ }^{\circ} \mathrm{C}, 99 \%$; (b) TBSOTf, $\mathrm{Et}_{3} \mathrm{~N}, \mathrm{CH}_{2} \mathrm{Cl}_{2}, 0{ }^{\circ} \mathrm{C}$, 98\%; (c) TBAF, AcOH, THF, rt, 78\% after three recycles; (d) Dess-Martin periodinane,

$\mathrm{CH}_{2} \mathrm{Cl}_{2}$, rt; (e) Bestmann reagent, $\mathrm{K}_{2} \mathrm{CO}_{3}, \mathrm{MeOH}$, rt; (f) $n$-BuLi, THF/HMPA (10:1), $-78^{\circ}$ $\mathrm{C}$; then MeI, rt, 99\% (three steps); (g) HF•pyridine, THF, rt, 96\%; (h) TESOTf, Et 3 N, $\mathrm{CH}_{2} \mathrm{Cl}_{2}, 0{ }^{\circ} \mathrm{C}, 99 \%$; (i) $\left(\mathrm{Me}_{2} \mathrm{PhSi}\right)_{2} \mathrm{Cu}(\mathrm{CN}) \mathrm{Li}_{2}$, THF, $-78 \rightarrow 0{ }^{\circ} \mathrm{C}$, regioselectivity = ca. 9:1; (j) NIS, MeCN/THF (3:1), rt, 99\% (two steps), $E: Z=6: 1$; (k) 5b, $\mathrm{Pd}_{2}(\mathrm{dba})_{3}, \mathrm{Ph}_{3} \mathrm{As}$, CuTC, DMSO/THF (1:1), rt, 63\%; (l) TBDPSCl, imidazole, DMF, $0{ }^{\circ} \mathrm{C}$, 99\%; (m) PPTS, $\mathrm{CH}_{2} \mathrm{Cl}_{2} /$ $\mathrm{MeOH}(4: 1), 0{ }^{\circ} \mathrm{C}, 75 \%$; (n) $\mathrm{SO}_{3} \bullet$ pyridine, $\mathrm{Et}_{3} \mathrm{~N}, \mathrm{CH}_{2} \mathrm{Cl}_{2} / \mathrm{DMSO}(3: 1), 0{ }^{\circ} \mathrm{C}$; (o) 4, $n$-BuLi, HMPA, THF, $-78^{\circ} \mathrm{C} \rightarrow \mathrm{rt}$, $97 \%$ (two steps); (p) $30 \% \mathrm{H}_{2} \mathrm{O}_{2}, \mathrm{NaHCO}_{3}$, THF, rt, 77\%; (q) TASF, THF/DMF (1:1), rt, 79\%; (r) $\mathrm{MnO}_{2}, \mathrm{CH}_{2} \mathrm{Cl}_{2}$, rt, quant. 
A

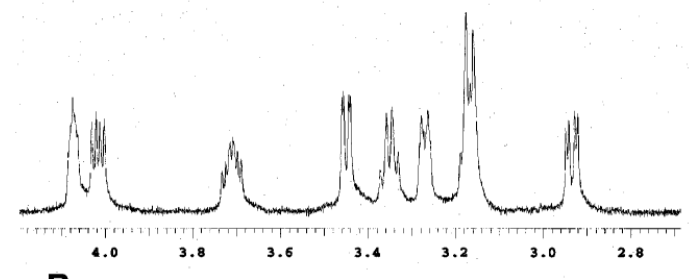

B

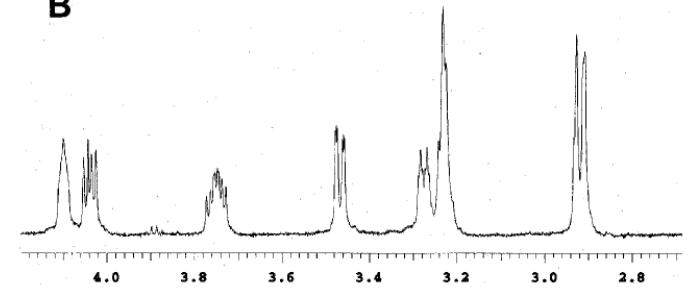

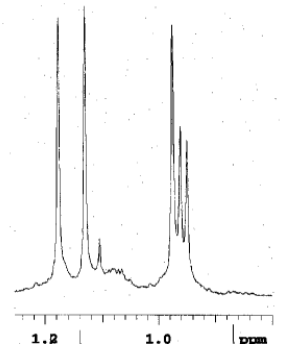

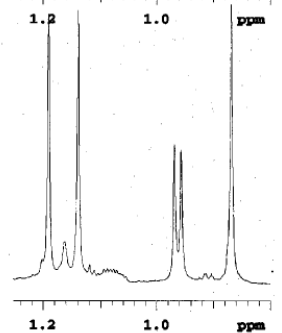

Figure 4.

Partial ${ }^{1} \mathrm{H}$ NMR spectra $\left(600 \mathrm{MHz}, \mathrm{C}_{6} \mathrm{D}_{6}\right)$ of the natural brevenal (panel A) and synthetic $\mathbf{1}$ (panel B). 


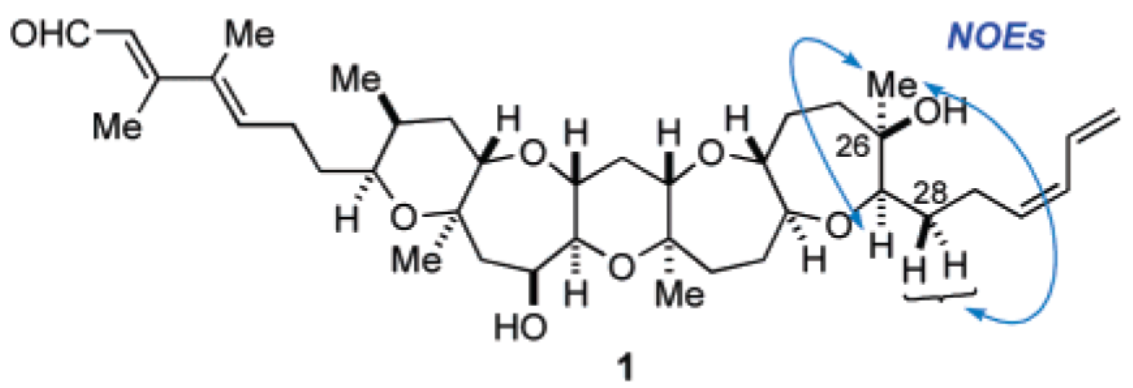

Figure 5.

Selected key NOE data for synthetic $\mathbf{1}$. 

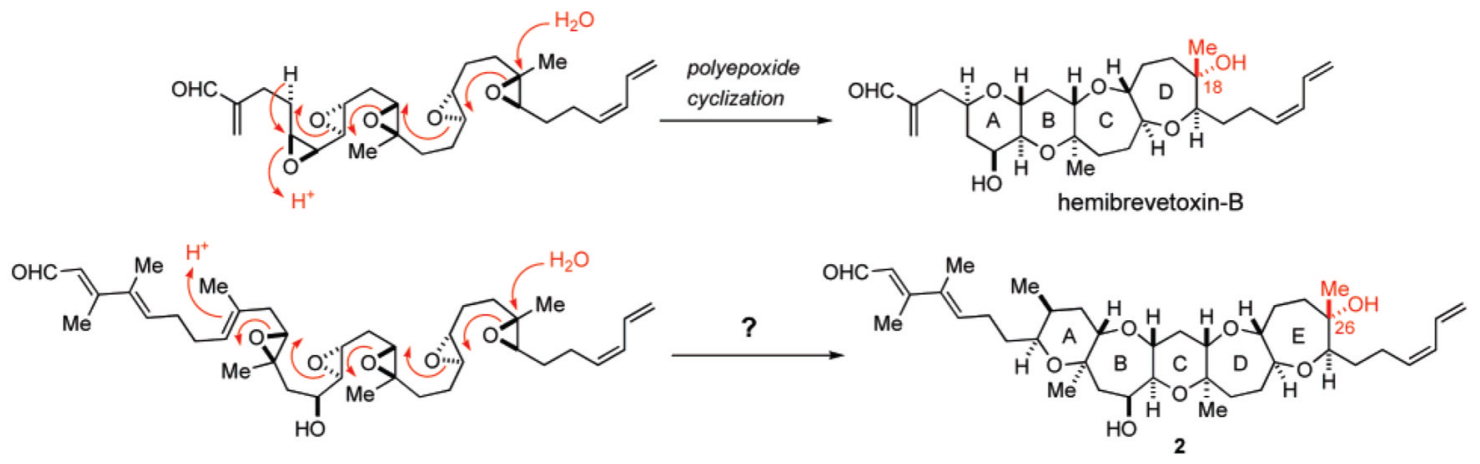

Figure 6.

Proposed biosynthetic pathway for marine polycyclic ether natural products. 

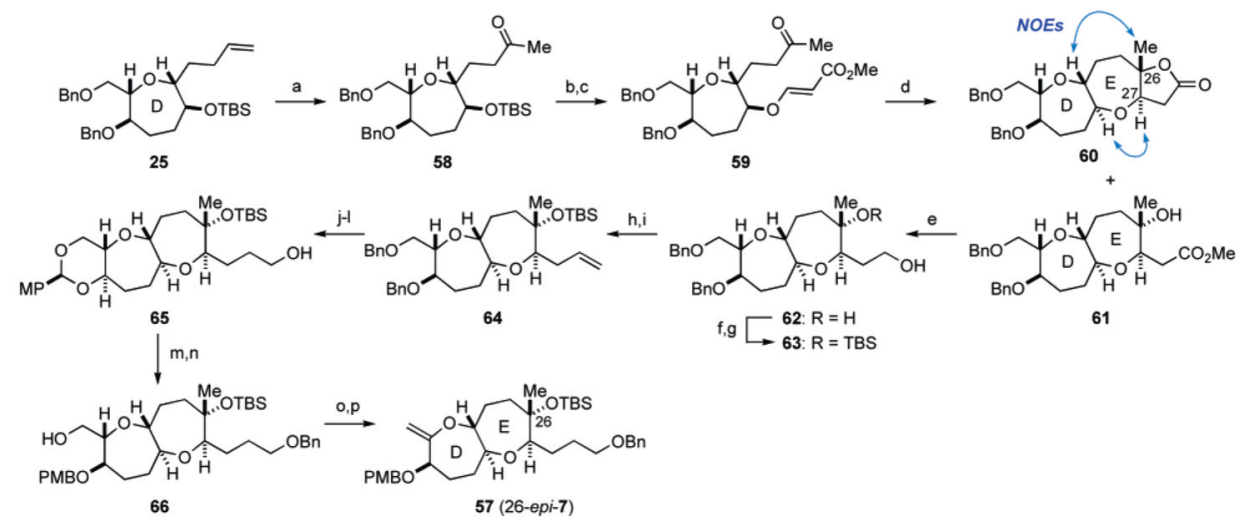

\section{Scheme 8.}

Synthesis of the 26-epi-DE Ring Fragment $57^{a}$

${ }^{a}$ Reagents and conditions: (a) $\mathrm{Cu}(\mathrm{OAc})_{2}, \mathrm{PdCl}_{2}, \mathrm{O}_{2}, \mathrm{DMA} / \mathrm{H}_{2} \mathrm{O}$ (7:1), rt, 92\%; (b) TBAF, THF, rt; (c) methyl propiolate, NMM, $\mathrm{CH}_{2} \mathrm{Cl}_{2}$, rt, $96 \%$ (two steps); (d) $\mathrm{SmI}_{2}, \mathrm{MeOH}$, THF, rt, $57 \%$ for $\mathbf{6 0}, 37 \%$ for $\mathbf{6 1}$; (e) $\mathrm{LiAlH}_{4}, \mathrm{THF}, 0{ }^{\circ} \mathrm{C}$, quant. from $\mathbf{6 0}$, quant. from $\mathbf{6 1}$; (f) TBSOTf, $\mathrm{Et}_{3} \mathrm{~N}, \mathrm{CH}_{2} \mathrm{Cl}_{2}$, rt; (g) CSA, $\mathrm{MeOH} / \mathrm{CH}_{2} \mathrm{Cl}_{2}(1: 1), 0{ }^{\circ} \mathrm{C}, 90 \%$ (two steps); (h) $\mathrm{SO}_{3} \cdot$ pyridine, $\mathrm{Et}_{3} \mathrm{~N}$, DMSO/ $\mathrm{CH}_{2} \mathrm{Cl}_{2}(1: 1), 0{ }^{\circ} \mathrm{C}$; (i) $\mathrm{Ph}_{3} \mathrm{P}^{+} \mathrm{CH}_{3} \mathrm{Br}^{-}$, NaHMDS, THF, $0{ }^{\circ} \mathrm{C}, 94 \%$ (two steps); (j) 9-BBN, THF, rt; then aq $\mathrm{NaHCO}_{3}, 30 \% \mathrm{H}_{2} \mathrm{O}_{2}$, rt; (k) $\mathrm{H}_{2}, 20 \% \mathrm{Pd}(\mathrm{OH})_{2} / \mathrm{C}, \mathrm{MeOH}$, rt; (l) $p$ - $\mathrm{MeOC}_{6} \mathrm{H}_{4} \mathrm{CH}(\mathrm{OMe})_{2}$, PPTS, $\mathrm{CH}_{2} \mathrm{Cl}_{2}$, rt, $80 \%$ (three steps); (m) BnBr, $\mathrm{KO} t-\mathrm{Bu}, n-\mathrm{Bu} u_{4} \mathrm{NI}$, THF, rt; (n) DIBALH, $\mathrm{CH}_{2} \mathrm{Cl}_{2},-78 \rightarrow 0{ }^{\circ} \mathrm{C}, 85 \%$ (two steps); (o) $\mathrm{I}_{2}, \mathrm{PPh}_{3}$, imidazole, benzene, rt; (p) KOt-Bu, THF, $0{ }^{\circ} \mathrm{C}, 98 \%$ (two steps). 

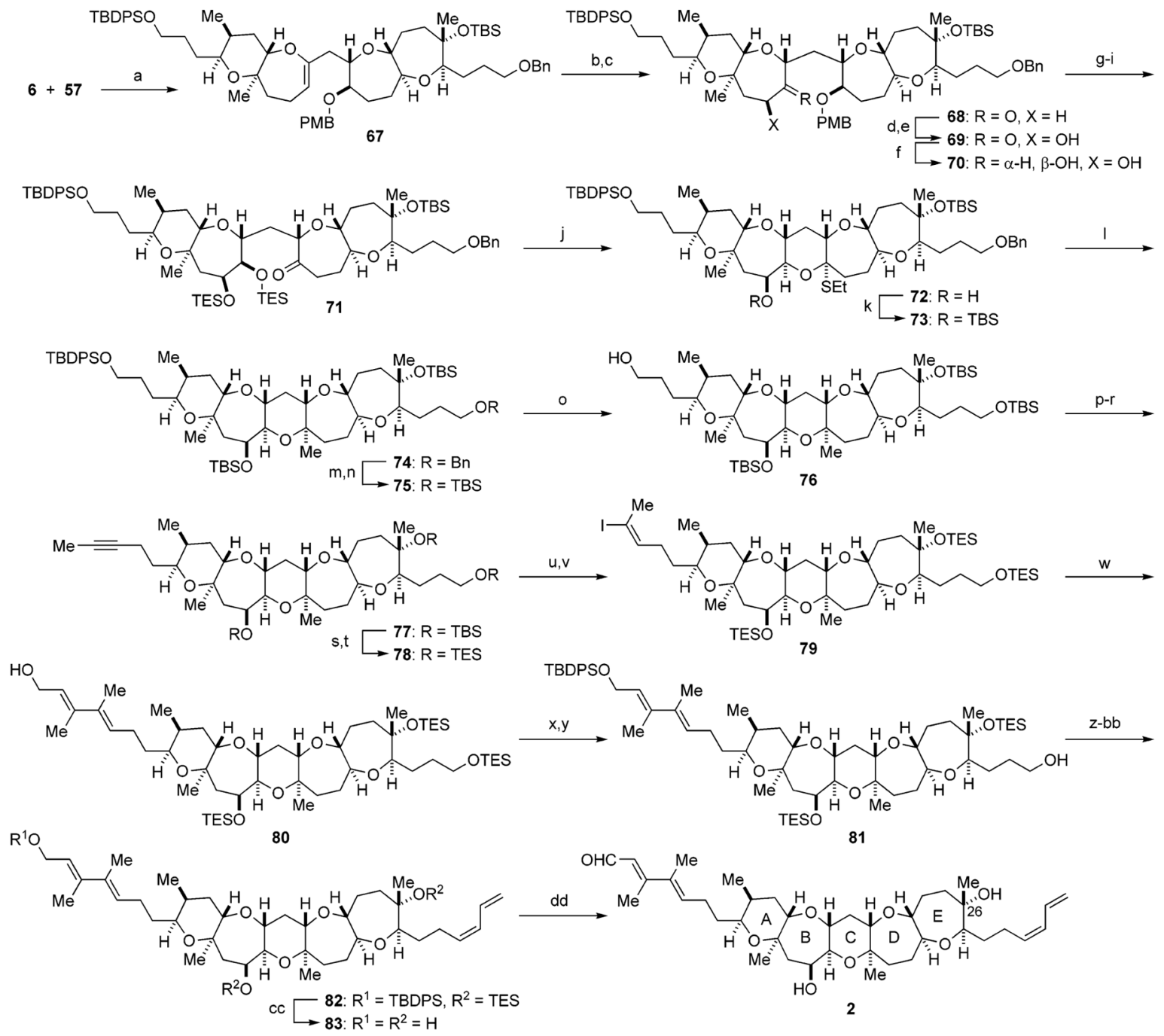

Scheme 9.

Total Synthesis of the Revised Structure 2 for Brevenal ${ }^{a}$

${ }^{a}$ Reagents and conditions: (a) 57, 9-BBN, THF, rt; then $3 \mathrm{M} \mathrm{aq} \mathrm{Cs}_{2} \mathrm{CO}_{3}, 6, \mathrm{Pd}\left(\mathrm{PPh}_{3}\right)_{4}, \mathrm{DMF}$, $50{ }^{\circ} \mathrm{C}$; (b) $\mathrm{BH}_{3} \cdot \mathrm{SMe}_{2}$, THF, rt; then aq $\mathrm{NaHCO}_{3}, 30 \% \mathrm{H}_{2} \mathrm{O}_{2}$, rt, $81 \%$ (two steps); (c) TPAP, NMO, $4 \AA$ molecular sieves, $\mathrm{CH}_{2} \mathrm{Cl}_{2}, 0{ }^{\circ} \mathrm{C}, 98 \%$; (d) LiHMDS, TMSCl, Et ${ }_{3} \mathrm{~N}, \mathrm{THF},-78{ }^{\circ} \mathrm{C}$; (e) $\mathrm{OsO}_{4}, \mathrm{NMO}, \mathrm{THF} / \mathrm{H}_{2} \mathrm{O}(4: 1), \mathrm{rt}, 83 \%$ (two steps); (f) DIBALH, THF, $-78{ }^{\circ} \mathrm{C}, 85 \%$ (+ diastereomer, 8\%; recovered 69, 3\%); (g) TESOTf, $\mathrm{Et}_{3} \mathrm{~N}, \mathrm{CH}_{2} \mathrm{Cl}_{2}, 0{ }^{\circ} \mathrm{C}$; (h) DDQ, $\mathrm{CH}_{2} \mathrm{Cl}_{2} /$ pH 7 phosphate buffer (10:1), rt; (i) TPAP, NMO, 4 A molecular sieves, $\mathrm{CH}_{2} \mathrm{Cl}_{2}$, rt, $88 \%$ (three steps); (j) EtSH, $\mathrm{Zn}(\mathrm{OTf})_{2}, \mathrm{CH}_{2} \mathrm{Cl}_{2}$, rt, 51\%; (k) TBSOTf, $\mathrm{Et}_{3} \mathrm{~N}, \mathrm{CH}_{2} \mathrm{Cl}_{2}, 0^{\circ} \mathrm{C} \rightarrow \mathrm{rt}, 86 \%$; (l) $m$ CPBA, $\mathrm{CH}_{2} \mathrm{Cl}_{2},-78{ }^{\circ} \mathrm{C}$; then $\mathrm{Me}_{3} \mathrm{Al}$ (excess), $-78 \mathrm{f} 0{ }^{\circ} \mathrm{C}, 94 \%$; (m) LiDBB, THF, $-78{ }^{\circ} \mathrm{C}$, 95\%; (n) TBSOTf, $\mathrm{Et}_{3} \mathrm{~N}, \mathrm{CH}_{2} \mathrm{Cl}_{2}, 0{ }^{\circ} \mathrm{C}, 99 \%$; (o) TBAF, $\mathrm{AcOH}$, THF, rt, $79 \%$ after two recycles; (p) $\mathrm{SO}_{3}$ •pyridine, $\mathrm{Et}_{3} \mathrm{~N}, \mathrm{CH}_{2} \mathrm{Cl}_{2} / \mathrm{DMSO}(3: 1), 0{ }^{\circ} \mathrm{C}$; (q) Bestmann reagent, $\mathrm{K}_{2} \mathrm{CO}_{3}$, $\mathrm{MeOH}, \mathrm{rt}$; (r) $n$-BuLi, THF/HMPA (10:1), $-78{ }^{\circ} \mathrm{C}$; then MeI, rt, $78 \%$ (three steps); (s) HF•pyridine, THF, rt, 97\%; (t) TESOTf, $\mathrm{Et}_{3} \mathrm{~N}, \mathrm{CH}_{2} \mathrm{Cl}_{2}, 0{ }^{\circ} \mathrm{C}, 89 \%$; (u) $\left(\mathrm{Me}_{2} \mathrm{PhSi}\right)_{2} \mathrm{Cu}(\mathrm{CN})$ $\mathrm{Li}_{2}, \mathrm{THF},-78 \rightarrow 0{ }^{\circ} \mathrm{C}$, regioselectivity = ca. 8.5:1; (v) NIS, MeCN/THF (3:1), rt, 88\% (two steps), $E: Z=$ ca. $6: 1$; (w) 5b, $\mathrm{Pd}_{2}(\mathrm{dba})_{3}, \mathrm{Ph}_{3} \mathrm{As}$, CuTC, DMSO/THF (1:1), rt, 60\%; (x) TBDPSCl, imidazole, DMF, $0{ }^{\circ} \mathrm{C}, 87 \%$; (y) PPTS, $\mathrm{CH}_{2} \mathrm{Cl}_{2} / \mathrm{MeOH}(4: 1), 0{ }^{\circ} \mathrm{C}, 70 \%$; (z) $\mathrm{SO}_{3} \cdot$ pyridine, $\mathrm{Et}_{3} \mathrm{~N}, \mathrm{CH}_{2} \mathrm{Cl}_{2} / \mathrm{DMSO}(4: 1), 0{ }^{\circ} \mathrm{C}$; (aa) $4, n$-BuLi, HMPA, THF, $-78{ }^{\circ} \mathrm{C} \rightarrow \mathrm{rt}$, 
99\% (two steps); (bb) 30\% $\mathrm{H}_{2} \mathrm{O}_{2}, \mathrm{NaHCO}_{3}$, THF, rt, 78\%; (cc) TAS-F, THF/DMF (1:1), rt, quant.; (dd) $\mathrm{MnO}_{2}, \mathrm{CH}_{2} \mathrm{Cl}_{2}, \mathrm{rt}, 76 \%$. 
Table 1

Stereoselective Methylation of Ketone 29

\begin{tabular}{|c|c|c|c|}
\hline entry & reagents and conditions & 30a:30b & $\%$ yield $^{a}$ \\
\hline $\begin{array}{l}1 \\
2 \\
3 \\
4 \\
5\end{array}$ & $\begin{array}{l}\mathrm{Me}_{3} \mathrm{Al}\left(10 \text { equiv), } \mathrm{CH}_{2} \mathrm{Cl}_{2},-78^{\circ} \mathrm{C} \rightarrow \mathrm{rt}\right. \\
\mathrm{MeMgBr}\left(10 \text { equiv), THF, }-78^{\circ} \mathrm{C}\right. \\
\operatorname{MeMgBr}\left(1.5 \text { equiv), THF, }-78^{\circ} \mathrm{C} \rightarrow \mathrm{rt}\right. \\
\operatorname{MeMgBr}\left(1.5 \text { equiv), toluene, }-78^{\circ} \mathrm{C} \rightarrow \mathrm{rt}\right. \\
\operatorname{MeLi}\left(1.2 \text { equiv), THF, }-78^{\circ} \mathrm{C} \rightarrow \mathrm{rt}\right.\end{array}$ & $\begin{array}{l}1.3: 1 \\
2.5: 1 \\
2.3: 1 \\
1: 1.3 \\
10: 1\end{array}$ & $\begin{array}{l}78(20)^{b} \\
36(52)^{b} \\
99 \\
\text { quant. } \\
97\end{array}$ \\
\hline
\end{tabular}


Table 2

Stille Coupling of Vinyl Stannane 5 and Vinyl Iodide $\mathbf{4 4}$

\begin{tabular}{|c|c|c|c|c|}
\hline & $\begin{array}{l}\text { 5a: } \mathrm{R}=\mathrm{TBDPS} \\
\mathbf{5 b}: \mathrm{R}=\mathrm{H}\end{array}$ & $44(E: Z=$ ca. $4: 1)$ & $\begin{array}{l}R=T B D P \\
R=H\end{array}$ & \\
\hline entry & vinyl stannane & reagents and conditions & $\%$ yield & $(\boldsymbol{E}, \boldsymbol{E}):(\boldsymbol{E}, \boldsymbol{Z})$ \\
\hline $\begin{array}{l}1 \\
2^{b} \\
3^{b} \\
4^{b} \\
5^{b} \\
6^{b} \\
7^{c} \\
8^{c}\end{array}$ & $\begin{array}{l}\mathbf{5 a} \\
\mathbf{5 b} \\
\mathbf{5 b} \\
\mathbf{5 b} \\
\mathbf{5 b} \\
\mathbf{5 b} \\
\mathbf{5 a} \\
\mathbf{5 a}\end{array}$ & $\begin{array}{l}\mathrm{PdCl}_{2}(\mathrm{MeCN})_{2}, \mathrm{DMF}, \mathrm{rt} \rightarrow 45^{\circ} \mathrm{C} \\
\mathrm{Pd}_{2}(\mathrm{dba})_{3},(2 \text {-furyl })_{3} \mathrm{P}, \mathrm{CuI}, \mathrm{DMSO} / \mathrm{THF}, \mathrm{rt} \\
\mathrm{Pd}_{2}(\mathrm{dba})_{3}, \mathrm{Ph}_{3} \mathrm{As}, \mathrm{CuI}, \mathrm{DMSO} / \mathrm{THF}, \mathrm{rt} \\
\mathrm{Pd}_{2}(\mathrm{dba})_{3},(2 \text {-furyl })_{3} \mathrm{P}, \mathrm{CuI}, \mathrm{DMSO} / \mathrm{THF}, 60^{\circ} \mathrm{C} \\
\mathrm{Pd}_{2}(\mathrm{dba})_{3}, \mathrm{Ph}_{3} \mathrm{As}, \mathrm{CuI}, \mathrm{DMSO} / \mathrm{THF}, 60^{\circ} \mathrm{C} \\
\mathrm{Pd}_{2}(\mathrm{dba})_{3}, \mathrm{Ph}_{3} \mathrm{As}, \mathrm{CuTC}, \mathrm{DMSO} / \mathrm{THF}, \mathrm{rt} \\
\mathrm{Pd}_{2}(\mathrm{dba})_{3}, \mathrm{Ph}_{3} \mathrm{As}, \mathrm{CuI}, \mathrm{DMSO} / \mathrm{THF}, \mathrm{rt} \\
\mathrm{Pd}_{2}(\mathrm{dba})_{3}, \mathrm{Ph}_{3} \mathrm{As}, \mathrm{CuTC}, \mathrm{DMSO} / \mathrm{THF}, \mathrm{rt}\end{array}$ & $\begin{array}{l}\text { trace } \\
57 \\
54 \\
48 \\
66 \\
84 \\
40 \\
69\end{array}$ & $\begin{array}{l}\mathrm{nd}^{a} \\
\text { ca. } 3.5: 1 \\
\text { ca. } 5: 1 \\
1: 1 \\
1: 1 \\
\text { ca. } 10: 1 \\
1: 0 \\
1: 0\end{array}$ \\
\hline 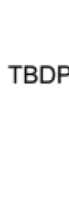 & -isomer & $\begin{array}{c}\text { Me } \\
\text { 47: homocoupling product }\end{array}$ & & \\
\hline \multicolumn{5}{|c|}{$a_{\text {nd }}=$ not determined } \\
\hline
\end{tabular}




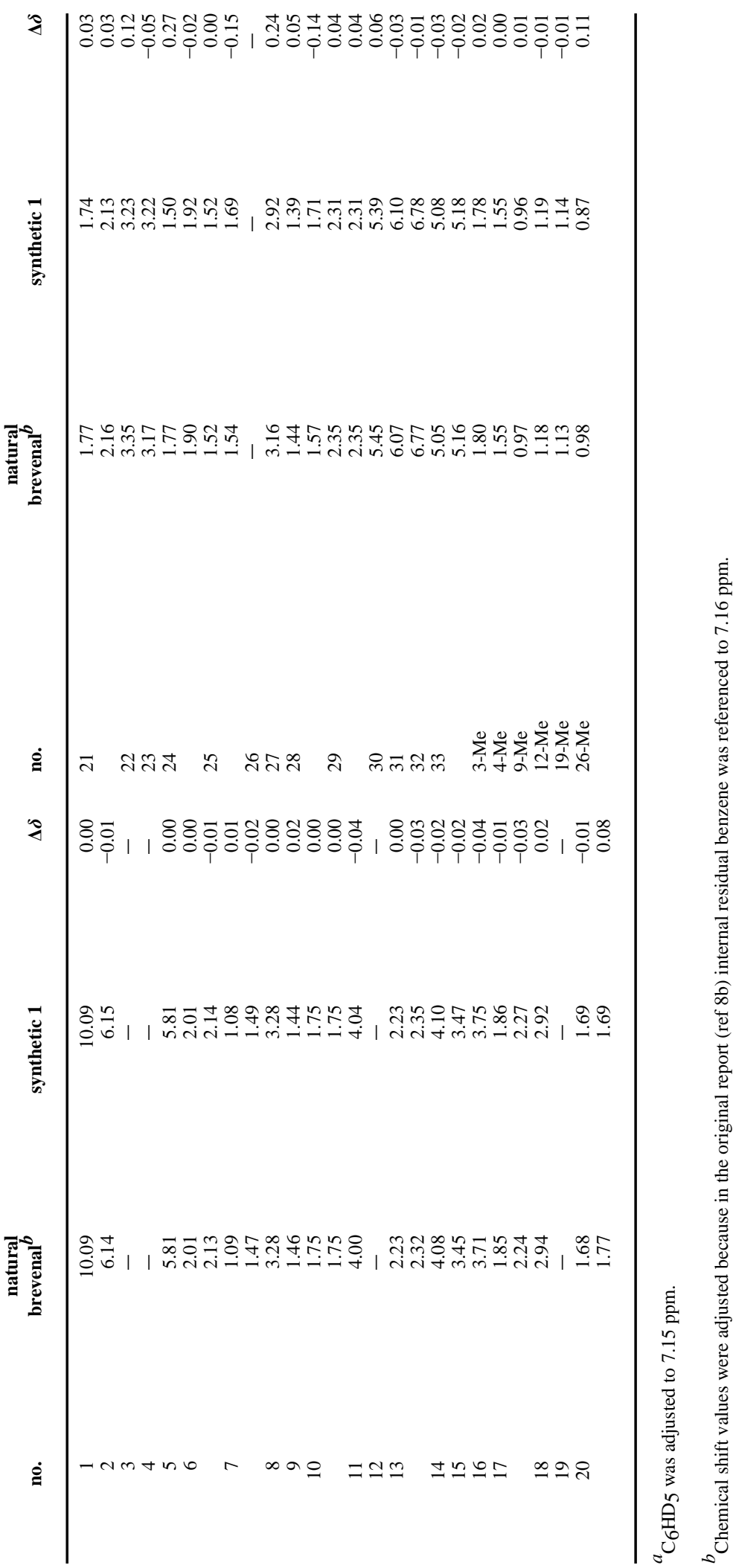




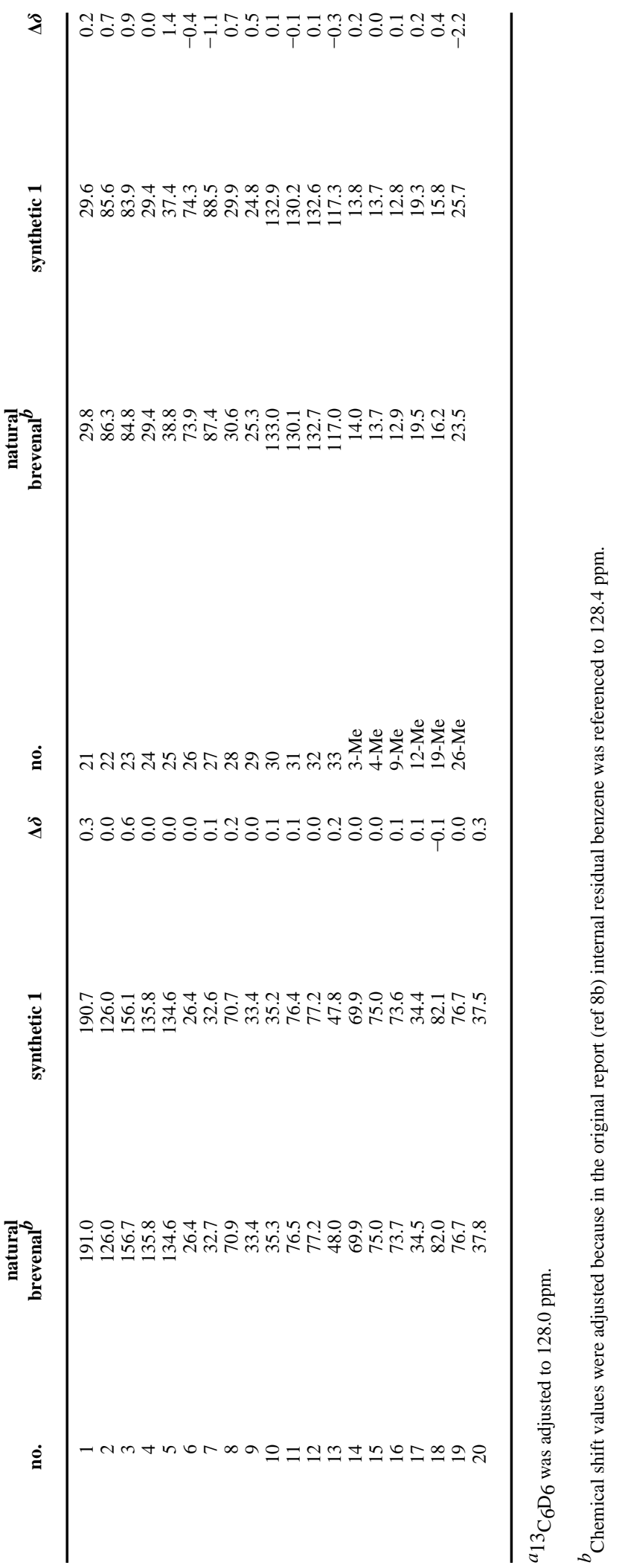

$J$ Am Chem Soc. Author manuscript; available in PMC 2008 October 29. 